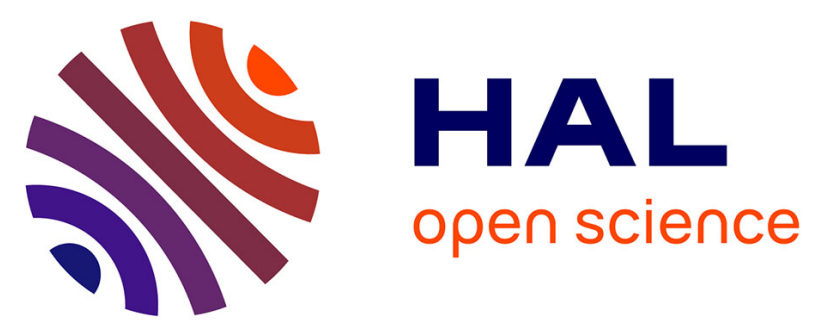

\title{
Deep structure of the Armorican Basin (Bay of Biscay): a review of Norgasis seismic reflection and refraction data
}

\author{
Isabelle Thinon, Luis Matias, Jean-Pierre Réhault, Alfred Hirn, Luis \\ Fidalgo-González, Félix Avedik
}

\section{To cite this version:}

Isabelle Thinon, Luis Matias, Jean-Pierre Réhault, Alfred Hirn, Luis Fidalgo-González, et al.. Deep structure of the Armorican Basin (Bay of Biscay): a review of Norgasis seismic reflection and refraction data. Journal of the Geological Society of London, 2003, 160, pp.99-116. 10.1144/0016-764901-103 . hal-00647845

\section{HAL Id: hal-00647845 https://hal-brgm.archives-ouvertes.fr/hal-00647845}

Submitted on 5 Jan 2012

HAL is a multi-disciplinary open access archive for the deposit and dissemination of scientific research documents, whether they are published or not. The documents may come from teaching and research institutions in France or abroad, or from public or private research centers.
L'archive ouverte pluridisciplinaire HAL, est destinée au dépôt et à la diffusion de documents scientifiques de niveau recherche, publiés ou non, émanant des établissements d'enseignement et de recherche français ou étrangers, des laboratoires publics ou privés. 
1 Deep structure of the Armorican Basin (Bay of Biscay): a review

2 of Norgasis seismic reflection and refraction data

3

\author{
Thinon $^{1}$, L. Matias ${ }^{2}$, J.P. RÉhault ${ }^{3}$, A. Hirn ${ }^{4}$, L. Fidalgo-GonzÁlez ${ }^{3,5}$ \& F. Avedik ${ }^{3,5}$ \\ ${ }^{11} B R G M-C D G / M A, 3$ avenue Claude Guillemin, BP 6009, 45060 Orléans cedex 2, France (e-mail: i.thinon@brgm.fr) \\ ${ }^{22}$ Centro de Geofisica, Rua da escola Politecnica 58, 1200 Lisbon, Portugal \\ ${ }^{33}$ IUEM-UBO, UMR6538 du CNRS, Place Nicolas Copernic 29280 Plouzané, France \\ ${ }^{44}$ Département de Sismologie, UA195 CNRS, IPG, 4 place Jussieu, 75252 Paris 05, France \\ ${ }^{55}$ IFREMER, DRO-GM, BP 70, Place Nicolas Copernic 29280 Plouzané, France
}

Received 30 July 2002; revised typescript accepted 27 August 2002

\title{
Abstract
}

The Bay of Biscay is bounded to the north by the North Biscay margin, which comprises the Western Approaches and Armorican segments. In the 1970s and 1980s, most researchers considered this margin typical of a non-volcanic passive margin: it is characterized by a striking succession of tilted blocks beneath which occurs the $S$ reflector and the continent-ocean boundary is abrupt. This paper examines the Armorican segment and is based on a study of all early seismic profiles together with new multichannel reflection and refraction seismic data (Norgasis cruise). An important result is the discovery of a $80 \mathrm{~km}$ wide ocean-continent transition zone that coincides with the Armorican Basin (a deep sedimentary basin). It is characterized by a high-velocity lower-crustal layer (7.4-7.5 $\left.\mathrm{km} \mathrm{s}^{-1}\right)$ overlain by sediments. The other results are: (1) the main crustal thinning occurs exclusively under the narrow continental slope; (2) the tilted blocks and the $S$ reflector are observed only at the base of the continental slope in the narrow domain called the 'neck area'; (3) the North Biscay Ridge is a large oceanic plateau present only off the NW Armorican margin rather than a long ridge elongated off the whole North Biscay margin.

Keywords: Bay of Biscay, passive margins, transition zones, rifting, crustal thinning.

\section{Introduction}

From the West Iberia margin to the Goban Spur margin, the zone of transition between thinned continental crust and typical oceanic crust was first proposed as a sharp transition, less than $10 \mathrm{~km}$ wide (e.g. Montadert et al. 1979a; Avedik et al. 1982; Derégnaucourt \& Boillot 1982; de Graciansky et al. 1985; Ginzburg et al. 1985; Boillot et al. 1987a; Whitmarsh et al. 1990; Pinheiro et al. 1992; Sibuet et al. 1992). More recently, off the West Iberia non-volcanic margin, seismic profiles and deep boreholes have indicated that this contact may involve a wider (30-120 km) zone referred to 
as the ocean-continent transition (e.g. Pickup et al. 1996; Whitmarsh \& Sawyer 1996) or the zone of exhumed continental mantle (Whitmarsh et al. 2001). The ocean-continent transition zone coincides with a very quiet magnetic zone (Whitmarsh et al. 1990) whose magnetic anomaly amplitudes are much lower than those of the well-known Cretaceous Magnetic Quiet Period.

Reflection profiles show that the upper basement rocks are very thin, with typically low velocities (between 4.5 and $6.0 \mathrm{~km} \mathrm{~s}^{-1}$ ), and are underlain by a lower basement layer characterized by high velocities of $7.2-7.6 \mathrm{~km} \mathrm{~s}^{-1}$ and by a complex reflectivity including both landward- and seawarddipping seismic reflectors (Pickup et al. 1996). This zone has a lack of Moho reflections (e.g. Chian et al. 1995, 1999, Louden \& Chian 1999). The deepest basement layer has seismic velocities between 7.2 and $7.6 \mathrm{~km} \mathrm{~s}^{-1}$ (e.g. Whitmarsh et al. 1990; Chian \& Louden 1994; Chian et al. 1995, 1999), which are lower than that measured within normal mantle $\left(8 \mathrm{~km} \mathrm{~s}^{-1}\right)$, and higher than that measured within the oceanic layer 3 or within lower continental crust $\left(6.5-7 \mathrm{~km} \mathrm{~s}^{-1}\right)$. This is a common feature of this and other ocean-continent transition zones and is referred to as the highvelocity lower-crustal layer (Louden \& Chian 1999). Currently, ocean-continent transition zones are interpreted variously as one of the following: (1) thinned continental crust intruded by melt from the mantle (Whitmarsh \& Miles 1995), which may represent transitional continental crust with more basic composition; (2) thin, tectonized oceanic crust produced by ultraslow sea-floor spreading (Srivastava \& Roest 1995; Srivastava et al. 2000); (3) tectonized underplated gabbros, as previously suggested for the Newfoundland Basin and Flemish Cap margins (Keen \& De Voogd 1988); (4) exhumed and variably serpentinized upper mantle, as suggested for the West Iberia margin (Boillot et al. 1980, 1987b; Girardeau et al. 1988; Sawyer et al. 1994; Whitmarsh et al. 1998; Chian et al. 1999; Whitmarsh et al. 2001). This last interpretation is also valid for the Labrador and western Greenland margins (Chian \& Louden 1994; Chian et al. 1995; Chalmers 1997), the Newfoundland Basin (Reid 1994), and the SW Australia margin (Nicholls et al. 1981). This last hypothesis has been supported by geological data obtained by dredging, drilling and using submersible off the West Iberia peninsula (e.g. Boillot et al. 1987b, 1988; Beslier et al. 1988; Girardeau et al. 1988; Sawyer et al. 1994; Whitmarsh et al. 1998) and by dredging off the Australian margin (Nicholls et al. 1981).

From these examples, there is general agreement for an ocean-continent transition zone formed during prolonged periods of extension with little or no melt generated from the upper mantle. Although the $7.2-7.6 \mathrm{~km} \mathrm{~s}^{-1}$ velocities are characteristic of the ocean-continent transition zones of some non-volcanic rifted margins, they are also observed beneath volcanic passive margins, where they would represent underplating gabbros or a lower continental crust intruded by mafic intrusions (Skogseid et al. 1992; White 1992a). One of the differences between volcanic and non-volcanic margins presented by White $(1992 \mathrm{a}, 1992 \mathrm{~b})$ concerns the adjacent oceanic crust, which is considerably thicker than normal off a volcanic margin and is thinner than normal off a non-volcanic margin. 
71 This paper examines the Armorican segment of the North Biscay margin from the continental shelf

72 to the oceanic crust. The principal aims of the study reported here were to identify more accurately 73 the boundaries between oceanic and continental crusts, to determine the location of the zone of 74 crustal thinning and to determine the crustal structure of the whole margin. Such data and geometric constraints are necessary for modelling the processes of continental break-up and of crustal thinning, the initiation of oceanic accretion, and kinematic reconstructions. The main result of this study is the discovery of a wide transitional domain between the typical continental and oceanic domains.

\section{Regional setting}

The Bay of Biscay (see Fig. 1) is a triangular oceanic domain bounded by two conjugate margins, the North Biscay margin and the North Iberia margin. The North Biscay margin comprises two segments: the Western Approaches margin (oriented $\mathrm{N} 110^{\circ}$ ) and the Armorican margin, with northern ( $\left.\mathrm{N} 110^{\circ}\right)$ and southern ( ${\left.\mathrm{N} 140^{\circ}\right)}^{\circ}$ components. A steep linear continental slope dominates the morphology of the North Biscay margin, disrupted only by the Meriadzek Terrace promontory in the Western Approaches domain collinear with the NE-SW axis of the English Channel Rift. The SE boundary of the Western Approaches margin with the Armorican margin is near the Black Mud Canyon and linked by the abrupt eastern termination of Meriadzek Terrace. At the base of the continental slope of the Armorican margin, we distinguish a deep basin, the Armorican Basin, limited to the west by the Trevelyan-Meriadzek complex and to the east by the Dôme Gascogne structure.

The relative movements between the North American, European and Iberian plates (e.g. Olivet 1996) during Early Cretaceous time induced the formation of the Bay of Biscay, contemporaneously with the opening of the North Atlantic Ocean. The absence of magnetic Chron MO in the Bay of Biscay and the age of the synrift sediments drilled on the Western Approaches margin (Montadert et al. 1979b) mark the beginning of rifting during the Early Cretaceous (140-110 Ma, Neocomian to Late Aptian) and the beginning of oceanic accretion in Late Aptian-earliest Albian time. Pre-rift sediments consist of Jurassic (150-140 Ma, Kimmeridgian to Portlandian) platform carbonates. As Chron 33 (80 Ma, Campanian) has not been recognized, the oceanic accretion of the Bay of Biscay ceased after Chron 34 (Fig. 2; Williams 1975). The later post-rift structural evolution of the Bay of Biscay is strongly linked to the Pyrenean orogenic phases induced by the Campanian-Oligocene (80-35 Ma) convergence of the Iberia peninsula towards Europe. This convergent movement also led to the partial closing of the Bay of Biscay and major deformation of the North Iberian margin. The Trevelyan Seamount (see Fig. 1) and the Dôme Gascogne are large structural inversions formed during the Pyrenean compressive phase (Debyser et al. 1971; Frappa \& Vaillant 1972; 104 Thinon et al. 2001). Recent studies of the Pyrenean phase emphasize a particular characteristic: the Armorican Basin is very weakly affected by the Pyrenean compressive deformation phase, which is 
intense only at its oceanic and continental domain boundaries (fig. 5 of Thinon et al. 2001). Rift structures are today preserved on the North Biscay margin and in the Parentis Basin (see Fig. 1).

\section{Background}

The Bay of Biscay was surveyed extensively in the 1970s and 1980s (Debyser et al. 1971; Montadert et al. 1971, 1974, 1979; Derégnaucourt \& Boillot 1982; Barbier et al. 1986; Le Pichon \& Barbier 1987). Oceanographic surveys began again in 1994 and 1997 (e.g. the Norgasis cruise; Avedik et al. 1996; Thinon 1999).

The North Biscay margin is usually considered to be a typical example of a non-volcanic passive margin (e.g. Montadert et al. 1974, 1979b; de Charpal et al. 1978; Avedik et al. 1982; Derégnaucourt \& Boillot 1982; Ginzburg et al. 1985; Barbier et al. 1986; Whitmarsh et al. 1986; Le Pichon \& Barbier 1987). From the few scattered seismic profiles shot off the Western Approaches margin across the Meriadzek-Trevelyan complex (Montadert et al. 1971), de Charpal et al. (1978) first observed a strong reflector below the tilted blocks, which they called the S reflector. Following these observations, most workers (e.g. Avedik \& Howard 1979; Montadert et al. 1979b) have shown that the Western Approaches margin from the shelf to the true oceanic crust is characterized by a striking succession of tilted fault blocks beneath which occurs the S reflector (Fig. 3a). The structural pattern of the Armorican margin is controversial. First, on the basis of subsidence history, the margin is characterized by significant crustal necking under the slope and by the lack of tilted blocks (Fig. 3b; Le Pichon \& Sibuet 1981). More recently, using the SNEAp seismic reflection dataset, Barbier et al. (1986) applied the global structural pattern of Montadert et al. (1979b) to the Armorican margin, and proposed that the Armorican margin was characterized, from the continental slope to the oceanic domain, by a succession of tilted blocks over the S reflector (Fig. 3c). From our new seismic dataset, we verify this crustal pattern.

The Armorican Basin is a thick sedimentary basin (5-7 km thick), discovered byBacon et al. (1969). Resting on the basement, Unit 3B, a seismically transparent unit characterized by velocities of 4.4 $\mathrm{km} \mathrm{s}^{-1}$ (Bacon et al. 1969) to $4.6 \mathrm{~km} \mathrm{~s}^{-1}$ (Avedik \& Howard 1979), is present (Fig. 4). Based on its morphology and acoustic facies, Unit 3B was interpreted as: (1) evaporites (Sibuet et al. 1971; Grau et al. 1973; Montadert et al. 1974; Derégnaucourt \& Boillot 1982); (2) basaltic rocks (Montadert et al. 1971; Grau et al. 1973); (3) pre-rift Cretaceous sediments (Barbier et al. 1986); (4) equivalent to the synrift formation of the Western Approaches margin (Montadert 1984). More recently, Unit 3B has been interpreted as a sedimentary body emplaced by slumping at the end of rifting phase (Thinon et al. 2002). This unit rests on a subhorizontal layer with high-amplitude and continuous reflections attributed to the top of the basement (Montadert et al. 1971, 1974; Sibuet et al. 1971; Grau et al. 1973) or to the S reflector (Barbier et al. 1986). Rather than being a typical oceanic crust (Limond et al. 1974), the substratum of the Armorican Basin is thought to consist of an extremely thinned $(<4$ km) continental crust (Fig. 3b and c; Grau et al. 1973; Avedik \& Howard 1979; Montadert et al. 
1979b; Le Pichon \& Sibuet 1981; Derégnaucourt \& Boillot 1982; Barbier et al. 1986). Uncertainties about the nature and the age of Unit 3B have led to controversy about the age of the Armorican Basin, the nature of its substratum and its origin. Different hypotheses postulated that the basin was: (1) created along a strike-slip fault system of the Hercynian Orogeny (Ziegler 1982); (2) the result of a late Triassic extensional phase (like the English Channel Rift and the Parentis Basin (Fig. 1) (Derégnaucourt \& Boillot 1982; Olivet 1996); (3) formed during the Early Cretaceous rifting of the Bay of Biscay (Debyser et al. 1971; de Charpal et al. 1978; Le Pichon \& Sibuet 1981). Using new seismic refraction and reflection data, we here describe the deep structure of the Armorican Basin so as to understand its origin.

The northern continent-ocean boundary of the Bay of Biscay was previously assumed to be sharp, less than 10 km in width (de Charpal et al. 1978; Avedik et al. 1982; Derégnaucourt \& Boillot 1982; Ginzburg et al. 1985; Whitmarsh et al. 1986). Most workers (e.g. Bacon et al. 1969; Debyser et al. 1971; Grau et al. 1973; Montadert et al. 1974, 1979b; Le Pichon \& Sibuet 1981) have postulated that this boundary is associated with a basement high called the North Biscay Ridge, which is crossed only by the OC17 seismic profile (Figs $3 b$ and 4). On the evidence of the continuity of a strong, linear and negative magnetic anomaly observed on the total magnetic field map (Le Borgne \& Le Mouël 1970; Fig. 2a), this basement high was inferred to extend along the entire North Biscay margin (see Fig. 2a; Montadert et al. 1979b; Derégnaucourt \& Boillot 1982). In this paper, we will show using our new seismic data and processed magnetic data that the North Biscay Ridge is unlikely to extend along the entire North Biscay margin. We will also discuss the occurrence in the Bay of Biscay of a wide ocean-continent transition zone.

\section{Seismic data acquisition and processing}

The structural analysis presented in this paper is mainly based on a reinterpretation of all the seismic profiles acquired between 1969 and 1981 (Fig. 1; e.g. Debyser et al. 1971; Montadert et al. 1979b; Vaillant 1988). They include a rectangular net of $6500 \mathrm{~km}$ of industry acquired and processed stacked multichannel seismic reflection profiles (with a 24-fold recording system) of the Société Nationale ELF (Barbier et al. 1986). These last lines (SNEAp), which we have reinterpreted, provide a shallow to deep crustal seismic image (10-12 s TWTT (two-way travel time) recording) of the North Biscay margin and of the Armorican Basin. Unfortunately, the SNEAp profiles off the Armorican margin do not reach the oceanic domain. These data are completed by new multichannel seismic reflection and refraction data collected during the Norgasis cruise.

The Norgasis seismic reflection profiles were acquired with a 96-channel streamer (25 m interval) using a single bubble array with 8-10 air guns and a generator capacity from 804 to 1230 in $^{3}$ (Avedik et al. 1993, 1996). Twenty-four-fold coverage was available with a $50 \mathrm{~m}$ shot interval. The $17 \mathrm{~s}$ TWTT recording provides deep crustal seismic images of the Armorican margin including the continental shelf, slope and the true oceanic areas. The Norgasis seismic refraction data (Fig. 1) 
were acquired using an array of 20 ocean-bottom seismometers developed at Hokkaido University by the LOBS Laboratory (Kanasawa \& Shiobara 1994). The instruments recorded continuously, providing a large set of long and short profiles together with many off-line sections. The seismic data were digitized at a $100 \mathrm{~Hz}$ sampling rate. When necessary, the instrument location was corrected by matching the observed and computed primary and first multiple water-wave arrivals. The initial crustal structure of the in-line profiles was obtained using the joint inversion and ray-tracing algorithm of Zelt \& Smith (1992). The main horizons identified in the sedimentary cover on the vertical incidence profiles were found to correspond to significant wide-angle reflectors and refractors so that their location measured in TWTT was kept fixed during the inversion. Only the layer velocities were allowed to vary. This restriction applied also to the MS and S horizons (see later). The deeper layers are better constrained by the ocean-bottom seismometer data and their positions were later compared with the vertical incidence data. The thickness, velocities and gradients of the different layers were refined by the use of synthetic seismograms computed by the method of Zelt \& Ellis (1988), which is based on asymptotic ray theory. The seismic refraction model, presented for the Norgasis 14 profile (see Fig. 7c, below) and discussed in the text, was built mainly from record sections obtained from seven ocean-bottom seismometers. However, because of the spacing of instruments (about $20 \mathrm{~km}$ ), many features of the velocity model are clearest on the strike profiles and the parallel profile near seismic line OC17 (see Fig. 6, below). In fact, the Norgasis 14 model represents a synthesis of the interpretation of the whole dataset.

The details of the analysis of the seismic refraction data will be presented in a forthcoming paper but some of the most relevant features are presented in Figure 5. The ray tracing that matches the interpreted travel time curves (Fig. 5a) shows that the deep structure is well constrained in two critical areas of the model. Travel time residuals are less than $0.1 \mathrm{~s}$, the estimated picking uncertainty. The layer densities were estimated from the P-wave velocity model using the curves obtained by Ludwig et al. (1970) and a 2D gravity model was obtained (Fig. 5b). Near the coast the seismic refraction model had to be slightly modified in the unconstrained part to obtain a good fit.

204 The density of the high-velocity lower-crustal layer was also reduced, corresponding to a difference 205 of $0.2 \mathrm{~km} \mathrm{~s}^{-1}$ in its original velocity (from 7.2 to $7.4 \mathrm{~km} \mathrm{~s}^{-1}$ ). The r.m.s. misfit between observed and 206 computed free-air anomalies is $3.0 \mathrm{mGal}$. The velocity and thickness of the high-velocity lowercrustal layer are constrained by refracted arrivals (phase $\mathrm{PH}$ ) and reflected arrivals from its top (phase PHP) and its base (phase PMP) (see Fig. $5 d$ and e). The high velocity contrast between Unit 3B $\left(5.2 \mathrm{~km} \mathrm{~s}^{-1}\right)$ and the high-velocity lower-crustal layer $\left(7.4 \mathrm{~km} \mathrm{~s}^{-1}\right)$ produces high-amplitude reflections, as illustrated by the observations and modelled by synthetic seismograms (Fig. 5e and

211 f). Refracted arrivals from the upper mantle (phase Pn) are also observed in some recordings (Fig. $2125 \mathrm{~d}$ ). The structure of the oceanic crust is deduced from refracted arrivals from layer 2 (P2) and layer 2133 (P3) (see Fig. 5c). Here the presence of the high-velocity lower-crustal layer is inferred by the 214 identification of both PHP and PMP arrivals that are conspicuous on several other record sections. 
215 More recently, we made a multibeam survey of this zone during the Zee-Gascogne cruise in 1997 216 on board the R.V. l'Atalante (Fig. 1). During this cruise, seismic reflection profiles were acquired at 21710 knots with a six-channel streamer, two Generator injector guns (105 in ${ }^{2}$ each), and with $10 \mathrm{~s}$ 218 TWTT recording. A conventional seismic processing scheme (stack, migration) using the ProMax 219 software was applied to the Norgasis and Zee-Gascogne reflection data (Thinon 1999). This 220 complete and homogeneous dataset (18 $000 \mathrm{~km})$ provides new information on the deep structure 221 across this non-volcanic passive margin.

\section{Interpretation}

223 From our data, we have divided the Armorican margin into five domains (Fig. 6) from the continental 224 domains (I, shelf; II, slope) to the oceanic domain (V). They are separated by a transitional domain 225 (IV), which does not present any characteristics of the others and which passes to the slope (II) 226 through a zone we call the 'neck area' (III). The Norgasis14 profile extends from domain I to domain 227 V (Fig. 7).

\section{The Armorican continental margin (domains I, II and III)}

229 The continental crust of the shelf comprises a non-reflective crust lying on a layered lower crust 230 (around $3 \mathrm{~s}$ TWTT thick) that displays horizontal, high-amplitude and low-frequency reflections (Fig. 231 8). At its base (at 10-11 s TWTT depth), there is a three-phase reflection with very high amplitude and low frequency. We interpret it as the Moho reflection, following a comparison with other seismic profiles across the continental shelf (Cazes et al. 1988; Dyment 1989). The continental crust is about 30-32 km thick with velocities of 5.8-6.1 km s-1 for the upper crust and $6.6-7.0 \mathrm{~km} \mathrm{~s}^{-1}$ for the lower crust (Avedik \& Howard 1979).

The continental slope exhibits a variable morphology (Fig. 1). Its northern segment constitutes a simple and steep slope (30 km wide, with a dip of $7^{\circ}$ ). The South Armorican slope is steep and narrower in its lower part (15 km wide with an average dip of $7^{\circ}$ ), and wider and weakly dipping $\left(<4^{\circ}\right)$ in its upper part. The seismic profiles show that the steep slope coincides with a major escarpment, which is exposed or covered by thin sediments (Figs 8 and 9). This escarpment constitutes the oceanward flank of a horst, which either bounds a hanging sedimentary basin in the upper part of the slope (Fig. 8) or marks the edge of the shelf (Fig. 9). Beneath the continental slope, no conspicuous tilted faulted blocks have been observed. Under the slope, the reflectivity of the lower continental crust is strongly attenuated on all seismic lines (Fig. 8). This could be an inherent feature of the acquisition and processing of seismic profiles in steeply dipping sea-floor areas. It could also reflect the rifting process (tectonic and thermal events and consequences of intra-crustal fluid circulation).

248 Faulted and tilted continental blocks are restricted to a deeper $30 \mathrm{~km}$ wide domain, at the base of the continental slope, and corresponding to the 'neck area' (zone III, Fig. 6). This is the last domain 
oceanward in which remnants of the continental crust have been observed. This domain contains several horsts, which can create relief at the foot of the slope (Figs 1, 4 and 7a), as well as a few tilted blocks (two successive blocks at most, Figs 10 and 11) and some shapeless faulted blocks (Figs 8 and 9). These blocks are uncommon, relatively small in size, $2 \mathrm{~s}$ TWTT thick at most, and less than $20 \mathrm{~km}$ wide. The tilted blocks include a very important pre-rift unit (1-2 s TWTT thick) lying on a portion of the crust (Figs 9 and 10). The refraction model along the Norgasis 14 profile (Fig. 7b) exhibits a horst with velocities from 5.4 to $6.2 \mathrm{~km} \mathrm{~s}^{-1}$ that confirms the presence of upper continental crust blocks in the 'neck area'. The blocks are tilted on a strong, continuous seismic horizon, which is identified as the $S$ reflector (Figs $7 a$ and 10 ) and coincides with a sharp seismic velocity contrast (6.2-6.8 $\mathrm{km} \mathrm{s}^{-1}$; Fig. 7b). We emphasize that on all seismic lines no direct seismic relation has been observed between the $S$ reflector and any structure or reflector within the continental slope. At the foot of the continental slope, the Norgasis reflection data show a deep-layered unit (Figs 7, 8 and 11). The top of this deep-layered unit coincides with the $S$ reflector. Its base is marked by a strong reflection that deepens landward, evolving from a single reflection at $9 \mathrm{~s}$ TWTT to a triple reflection at $10 \mathrm{~s}$ TWTT (Figs 8 and 11). The internal reflections characterizing this unit are truncated by or wedged out above its base, which we have attributed to the crust-mantle boundary (Fig. 11). This deep-layered unit is thus sandwiched between the $\mathrm{S}$ reflector and the shallow top of the mantle. The vertical velocity distribution (Fig. $7 \mathrm{~b}$ ) shows that this deep-layered unit has velocities ranging from 6.8 to $6.9 \mathrm{~km} \mathrm{~s}^{-1}$, similar to those of the lower continental crust. The unit vanishes toward the ocean and seems to also have no direct seismic relation with the layered lower continental crust observed under the shelf. The nature of this deep-layered unit remains open: it could be thinned lower

\section{Transitional domain (domain IV)}

273 Along the Armorican margin, the continental and oceanic domains are separated by an $80 \mathrm{~km}$ wide 274 transitional domain (zone IV, Fig. 6), associated with a magnetic signature characterized by low275 amplitude magnetic anomalies, without linearity, similar to a very quiet magnetic zone (Fig. 2b). Its 276 eastern part exhibits some discrete, strong and positive magnetic anomalies. The acoustic facies of 277 its substratum has neither the characteristics of the continental crust nor those of the oceanic crust.

278 Substratum of transitional domain. Throughout the transitional domain, the top of the substratum is 279 an acoustic reflector, the MS reflector that gives rise to reflections with high amplitudes and low 280 frequencies that were in the past considered to represent the $S$ reflector. The MS reflector 281 systematically truncates the dipping reflectors (DR) in the underlying material (Figs 7, 8 and 12). It is 282 situated at depths of 8-9.5 s TWTT (Figs 7 and 12). Its regional topography is characterized by 283 large wavelength bulges (Fig. 13), generally independent of the overlying structures. This indicates 284 that the bulges formed just before deposition of the first post-rift sediments (Figs 4, 7 and 12). 
The MS reflection is generally continuous and smooth (Fig. 12a), except in the eastern landward zone, under Unit $3 \mathrm{C}$, where it is discontinuous with a low amplitude or is suggested to exist indirectly by the upward terminations of the dipping underlying reflectors (DR) (Fig. 12b). On Norgasis data, acquired in the western part, the MS reflector coincides with a clear seismic contrast (5.0-5.2 $\mathrm{km} \mathrm{s}^{-1}$ v. $7.4 \mathrm{~km} \mathrm{~s}^{-1}$ ), at the top of a 3-4 km thick layer with velocities of $7.4-7.5 \mathrm{~km} \mathrm{~s}^{-1}$ (Fig. 7b) called the high-velocity lower-crustal layer by Louden \& Chian (1999). The base of the highvelocity lower-crustal corresponds to a deeper and discontinuous reflector we call the Mn reflector. It coincides with a velocity contrast $\left(7.5 \mathrm{~km} \mathrm{~s}^{-1} \mathrm{v} .8 .0 \mathrm{~km} \mathrm{~s}^{-1}\right)$ underlying the Moho. The high-velocity lower-crustal is associated with the upper part of the substratum containing the DR reflections. The DR reflections are high-amplitude, low-medium-frequency, dipping seismic reflections, interrupted by the MS reflection. Their distribution and their orientation, which includes constant dips, seem to be a function of the topography of the substratum, as they are more important on the side of the bulges (Figs $7 \mathrm{~b}$ and 13).

The overlying materials. The landward transitional domain is characterized by Units $3 \mathrm{~B}$ and $3 \mathrm{C}$ overlying the MS reflector (Figs 6 and 12). Unit 3B, observed in the western Armorican transitional zone, is a seismic unit with low reflectivity (Figs 7 and 12a). It has velocities from 4.6 to $5.3 \mathrm{~km} \mathrm{~s}^{-1}$, with a positive velocity gradient, and a thickness of 0-3300 m (Fig. 7b). Its top and bottom (MS reflector) are continuous and smooth seismic horizons. On the seismic reflection profiles, Unit 3B appears generally as a half-lens with a horizontal base (Fig. 12a), or a thick 'incompetent' body, which pinches out towards the ocean (Fig. 9). From the seismic correlations, Thinon et al. (2002) showed that Unit 3B is a sedimentary body emplaced by slumping at the end of the rifting phase, because of its emplacement between the break-up unconformity and the synrift formation of the Western Approaches margin. Unit $3 \mathrm{C}$ is observed exclusively in the landward area of the eastern Armorican transitional domain (Fig. 6). It is bounded at its top by a strongly refractive and irregular reflection (Fig. 12b) and at its base by the MS reflection, which is here discontinuous and of low amplitude. On the Loire Maritime 2 profile (Fig. 12C), Unit 3B seems to onlap 3C. Our data do not permit us to identify the nature of Unit $3 \mathrm{C}$.

Along the oceanic domain, in the oceanward transitional zone, the MS reflector is generally covered directly by a set of conformable seismic reflectors interpreted as Aptian-Cenomanian post-rift sediments (e.g. Derégnaucourt \& Boillot 1982; Thinon 1999). It is locally interrupted by a few important bodies (2 s TWTT thick) that present conical to ridge shapes with flat tops that may represent a pre-Pyrenean erosion surface (Figs 6 and 14). The conical structures may be volcanoes and the basement ridges may be volcanic ridges, consistent with the presence of some discrete, high and positive magnetic anomalies (Fig. 2). Alternatively, they could be peridotite ridges as seen off the West Iberia margin (e.g. Boillot et al. 1980, 1987b, 1988; Beslier et al. 1988; Girardeau et al. 1988; Sawyer et al. 1994; Whitmarsh et al. 1998). 
321 Other structures, called ST, are also observed on a disrupted MS reflector (Fig. 7b) around the 322 conical and ridge structures described above. They have a 'chaotic' acoustic facies and are $0.2 \mathrm{~s}$ 323 TWTT thick. The top is only suggested by the interruption of the reflectors belonging to the overlying 324 sedimentary unit (Unit 3). From acoustic facies, this feature may be interpreted as a volcano325 sedimentary series or volcanic extrusive rocks. Its velocity is too high (6 km s$~^{-1}$, Fig. $\left.7 \mathrm{~b}\right)$ for 326 uppermost oceanic crust (White 1992b).

327 Boundaries of the transitional domain. The geometric relations between the continental and the 328 transitional domains are well imaged on the Norgasis lines (Fig. 11). The oceanward continental 329 block of the 'neck area' corresponds approximately to the junction of the S, M and MS reflectors 330 (Figs 7, 8 and 11). Figure 11c shows that the MS reflector lies on the prolongation of the junction 331 between the $\mathrm{M}$ reflector (continental Moho) and $\mathrm{S}$ reflector (base of tilted blocks and top of the 332 deep-layered unit).

333 The relationship between the transitional domain of the Western Armorican Basin and the true 334 oceanic domain is atypical, as locally the high-velocity lower-crustal penetrates the oceanic zone 335 (Fig. 7). Here, it underplates a large basement high (8 s TWTT deep, $60 \mathrm{~km}$ wide and $100 \mathrm{~km}$ long) 336 with seismic velocities in the range of $4.5-7.0 \mathrm{~km} \mathrm{~s}^{-1}$ that we interpret as oceanic crust. This 337 basement high would coincide with the North Biscay Ridge defined in the 1970s (see the 338 Background section). Contrary to the initial hypothesis, our new seismic data show that this 339 basement high forms a large plateau, only off the north segment of the Armorican margin (Fig. 6). 340 Compared with the whole oceanic domain, this basement high has a reduced sedimentary cover 341 (Fig. 7), with no Aptian-Cenomanian sediments (Unit 3). This observation suggests that this relief 342 was initiated before the Paleocene to Oligocene Pyrenean compression, certainly during the early 343 spreading phase. This local oceanic structure can be compared with that described on the Vöring 344 margin where underplated low-density materials have induced the uplift of the oceanic crust and 345 significant erosion of its sedimentary cover (Skogseid et al. 1992). The underplating of the high346 velocity lower-crustal could have produced a relative and local uplift of the observed oceanic 347 plateau.

\section{True oceanic domain (domain V)}

349 Apart from the large oceanic plateau described above, the acoustic basement of the oceanic 350 domain is 8.5-9 s TWTT deep, shallower than that of the ocean-continent transition zone. It is 351 strongly diffractive and irregular, similar to that of an oceanic crust. The vertical distribution of the 352 seismic velocities is also representative of typical oceanic crust with a 4.4-5.0 $\mathrm{km} \mathrm{s}^{-1}$ layer 2 and $3536.2-7.0 \mathrm{~km} \mathrm{~s}^{-1}$ layer 3. The depth of the base of the crust is $10 \mathrm{~s}$ TWTT. The well-controlled velocity 354 model indicates that the oceanic crust is $3-5 \mathrm{~km}$ thick, thinner than average normal oceanic crust $355(6-8 \mathrm{~km})$. This last observation agrees with other seismic measurements along the non-volcanic 356 North Atlantic continental margins (Ginzburg et al. 1985; Whitmarsh et al. 1990; Pinheiro et al. 1992; 
White 1992a, 1992b), which show an abnormally thin oceanic crust immediately adjacent to the continent-ocean transition. White (1992a, 1992b) suggested that the cause might be very slow seafloor spreading.

The magnetic anomalies of this domain have high amplitudes and a weakly marked linearity. They are similar to those of the North Atlantic Ocean between the magnetic Chron 34 and the magnetic Chron MO (Macnab et al. 1995), which characterizes the Cretaceous Magnetic Quiet Period.

To a first approximation, our interpretation of the beginning of the oceanic domain agrees with the sharp ocean-continent boundary of de Charpal et al. (1978) and Derégnaucourt \& Boillot (1982) (Fig. 1). Most workers (e.g. Bacon et al. 1969; Grau et al. 1973; Montadert et al. 1979b; Le Pichon \& Sibuet 1981; Derégnaucourt \& Boillot 1982; Barbier et al. 1986) have postulated that the large negative magnetic anomaly observed on the total magnetic field map (Fig. 2a) is the magnetic signature of a basement ridge, the North Biscay Ridge, observed only on the OC17 profile (Figs 3b and 4). On the map of magnetic anomalies reduced to the pole (Fig. $2 b$ ), this large negative magnetic anomaly does not exist, but a strong magnetic gradient separates domain $\mathrm{V}$ from domain IV (the very quiet magnetic zone). This observation agrees with the new seismic data, which show that the North Biscay Ridge is not a basement ridge but a large and local plateau (Fig. 6).

Comparison of the seismic and magnetic data shows that the boundary between the oceanic domain and the transitional domain identified on the seismic profiles coincides globally with a strong magnetic gradient (Figs 2 and 6). However, off the eastern Armorican margin, a small shift exists between the limits of the oceanic domain deduced from seismic data and magnetic data (Fig. 6). This shift coincides with the presence of the ST bodies and some basement ridges, oriented WNWESE and situated in the western prolongation of the Dôme Gascogne. These elements may have a strong magnetic signature that influences the oceanic limit drawn from the magnetic data.

\section{Discussion}

\section{The ocean-continent transition zone}

The main characteristics of the Armorican ocean-continent transition zone. The seismic data have allowed us to image the ocean-continent transition zone along the Armorican margin. This zone, previously considered as a sharp contact (Derégnaucourt \& Boillot 1982), is in fact a wide zone (c. $80 \mathrm{~km}$ ) that coincides with the Armorican Basin (Fig. 6). This transitional domain shares the principal characteristics of other ocean-continent transition zones surveyed: a very 'quiet' magnetic signature, occurrence of shallow high-velocity materials (high-velocity lower-crustal layer), and the existence of a subhorizontal and smooth basement surface (MS reflector), which systematically overlies a complex reflectivity zone including both landward- and seaward-dipping reflectors (DR reflectors). However, the Armorican ocean-continent transition zone shows some distinctive 
features in comparison with other ocean-continent transition zones. It is marked by the presence of Moho reflections (Mn reflector) beneath the ocean-continent transition zone, by the occurrence of volcanic bodies in proximity to the oceanic domain and by particularities of the high-velocity lowercrustal layer, which is covered directly by sediments and overlies Moho reflections. Locally this highvelocity lower-crustal layer penetrates the oceanic domain, where it underplates the thin Cretaceous oceanic crust.

Nature and origin of the high-velocity lower-crustal layer. The high-velocity lower-crustal layer has velocities (7.4-7.5 $\left.\mathrm{km} \mathrm{s}^{-1}\right)$ lower than those measured within the normal mantle $\left(8 \mathrm{~km} \mathrm{~s}^{-1}\right)$, and greater than those measured within oceanic layer 3 or the lower continental crust $\left(6.5-7 \mathrm{~km} \mathrm{~s}^{-1}\right)$. Various interpretations of the high-velocity lower-crustal layer have been formulated (see the first section of this paper). It could be oceanic material, produced by ultraslow sea-floor spreading (Srivastava et al. 2000). However, the smooth character of the MS reflector is not typical of the surface of oceanic crust, the velocities of the basement are too high and this area has no linear magnetic anomalies (Fig. 2b). Second, this material could represent an extremely thinned, and possibly broken up, continental crust underplated and intruded by partial melt generated by asthenospheric upwelling, as suggested by Whitmarsh et al. (1990) for the Tagus Abyssal Plain. In this case the DR reflectors, which characterize the seismic facies of the high-velocity lower-crustal layer, could represent traces of the volcanic intrusions. However, the existence of an extremely thinned continental crust ( $<4 \mathrm{~km}$ thick), with a smooth surface, without conspicuous structures, throughout the Armorican Basin, seems to us unlikely. Third, the high-velocity lower-crustal layer could be mafic magmas underplated during the rifting period, as shown by underplating beneath other volcanic rifted margins (Skogseid et al. 1992; White 1992a), but also beneath the Iberia Abyssal Plain non-volcanic margin (Cornen et al. 1996, 1999) and, further south, in the Gorringe Bank area (Girardeau et al. 1998), where a $5 \mathrm{~km}$ thick by $80 \mathrm{~km}$ long gabbro body was described at the top of the mantle. Our data cannot exclude such an origin. Another possibility is to consider the high-velocity lower-crustal layer as an abnormal hydrated mantle that extends along the entire West Iberia margin. In this case, the DR reflectors (Fig. 12) may represent faults, important for serpentinization, and the bulges of the substratum (Fig. 13) may correspond to serpentinite diapirs induced by a volume increase as a result of serpentinization (Recq et al. 1996).

This last interpretation of the high-velocity lower-crustal layer is supported by its seismic structure, which presents some characteristics comparable with other ocean-continent transition zones: the landward- and seaward-dipping reflectors (DR reflectors) under the MS reflector are comparable with those described in the West Iberia ocean-continent transition zone by Pickup et al. (1996). Its geographical position against the continental slope, its width and its magnetic signature are comparable with those of the West Iberia margin. The overlying material can also be compared with that found off the West Iberia margin: Unit 3B (Figs 9 and 12a) exhibits a similar seismic signature to that of the Enigmatic Terrane described on Galicia Bank by Boillot et al. (1995). Also, the seismic 
image of Unit 3C (Fig. 12b) exhibits numerous similarities with images from the Iberia Abyssal Plain basement (see Fig. 16b, below; Pickup et al. 1996). If this last interpretation is correct, it implies that the rifting in the Bay of Biscay took place, at least initially, with little or no magmatic activity.

\section{The nature of the 'neck area' and its significance}

The 'neck area' (zone III, Fig. 6) is the last domain oceanward, at the foot of the continental slope, where structural elements attributed to the continental crust have been observed. The rare tilted blocks are restricted to this area. They comprise a low crustal thickness and a thick pre-rift unit. They could also represent a few fragments of the more superficial part of the upper continental crust. There are very few tilted blocks along the Armorican margin (five at most) compared with the Western Approaches margin (e.g. Montadert et al. 1979b; Whitmarsh et al. 1986; Fig. 2a).

The blocks overlie variable crustal materials, such as the deep-layered crust or the high-velocity lower-crustal layer (Figs 8 and 11). If we follow the conventional hypothesis these blocks reflect a normal product of the stretching phase of the continental crust. However, according to Montadert et al. (1979b) and Chenet et al. (1983), who worked on the Western Approaches margin, the extension rate calculated from the tilted block geometry is too low to justify an overall crustal thinning. The few blocks observed off the Armorican margin have a similar involvement. An alternative implication is to consider that these blocks represent gravity slide structures related to the flexural subsidence of the margin. In this case, the tilted blocks are uninvolved in the processes of crustal thinning. The 'neck area' would represent a 'glide block area' and the true limit of the continental domain (the locus of continental break-up) would be situated at the base of the slope. The continental slope would therefore give, apart from rare exceptions, a good approximation of the precise extent of the continent domain.

A similar deep-layered unit observed on the Norgasis profiles (Figs 7, 8 and 11) is observed also at the foot of the West Iberia continental slope: the IAM 9 profile (see Fig. 16c, below) indeed exhibits some small tilted blocks resting on a highly reflective material including landward-dipping reflectors. This deep-layered unit could correspond to a part of the thinned and stretched layered lower continental crust, as it displays similar seismic facies and velocities. However, we do not have direct seismic data that allow us to confirm a genetic relationship between the deep-layered unit and the layered lower continental crust of the shelf. Alternatively, this deep-layered crust could be new crust, possibly underplated during the rifting phase. In the latter case, the base of the continental slope would be the locus of the continental break-up.

Previous interpretations of the $S$ reflector suggested that it corresponds to: (1) the brittle-ductile transition within continental crust (de Charpal et al. 1978; Le Pichon \& Barbier 1987), or as deduced from the Galicia margin; (2) a detachment fault that penetrates the entire lithosphere (Boillot et al. 1989); (3) an intra-crustal detachment fault (Sibuet 1992); (4) a detachment between upper 
464

465

466

467

468

469

470

471

472

473

474

475

476

477

478

479

480

481

482

483

484

485

486

487

488

489

490

491

492

493

494

495

496

497

498

continental crust material and serpentinized upper mantle (Boillot et al. 1989; Chian et al. 1995); (5) a complex boundary with features (3) and (4) (Boillot et al. 1995; Reston 1996; Reston et al. 1996); (6) an abrupt transition between the faulted upper continental crust and the top of the high-velocity lower-crustal layer (Louden \& Chian 1999). Along the Armorican margin, the S reflector is observed only off the continental slope, in the 'neck area'. Its occurrence always coincides with the presence of tilted fault blocks. It therefore corresponds most closely to a décollement surface, on which the faulted blocks have moved and rotated. This interpretation is in agreement with that of Avedik et al. (1982) and Barbier et al. (1986) on the Western Approaches margin.

The lack of relationship between these structures and the faults of the upper continental slope excludes the hypothesis that the $\mathrm{S}$ reflector is the trace of a long, low-angle detachment, i.e. continuation of a 'breakaway' as often suggested (Barbier et al. 1986; Boillot et al. 1987b, 1989; Sibuet 1992; Reston 1996; Reston et al. 1996; Manatschal \& Nievergelt 1997). On the Norgasis reflection and refraction data, the $S$ reflector appears to be the prolongation of the top of the highvelocity lower-crustal layer that corresponds to the MS reflector (Fig. 11). On the basis of our whole seismic reflection dataset, it appears that the $S$ reflector corresponds to an intra-crustal detachment surface of tilted blocks, and evolves towards the ocean into interfaces between faulted blocks and either the deep-layered crust or the upper mantle (Boillot et al. 1987a, 1995; Reston 1996; Reston et al. 1996; Manatschal \& Nievergelt 1997; Louden \& Chian 1999). Off the Armorican margin, the S reflector has no direct seismic relationship with the location of crustal thinning. We think that the $S$ reflector has restricted influence within the zone of tilted blocks and seems to have had a minor role in the crustal thinning processes.

\section{The thinning of the continental crust}

Our data demonstrate that crustal thinning of the Armorican margin is restricted to a very narrow area that corresponds to the continental slope, of $15-50 \mathrm{~km}$ width. The seismic profiles show that the crustal thickness decreases under the continental slope from about $35 \mathrm{~km}$ at the shelf break to less than $10 \mathrm{~km}$ at the foot of the slope (Fig. 8b). The crustal thinning is underlain by a major escarpment, which breaks the upper crust above a striking Moho rise. The apparent expression of the crustal thinning is thus only a very small amount of extension in the upper continental crust. The behaviour of the layered lower continental crust beneath the slope is not well imaged by our data, as a result of the reflectivity loss, but the steep rise of the mantle implies its disappearance (Fig. 8a). The domain immediately at the foot of the continental slope corresponds to the 'neck area', which displays some faulted blocks separated from a deep-layered unit by the S reflector. The tilted blocks are considered here to be gravity slide structures. We consider thus that the continental slope represents, as a first approximation, the locus of the initial continental break-up.

\section{Conclusions}


499 Integration of the new seismic reflection and refraction data, from the continental shelf to the 500 oceanic domain, highly constrains the shallow and deep structure of the Armorican margin. 501 Interpretation of the entire seismic dataset has resulted in a structural map of the Armorican margin 502 that defines five main domains: the unextended continental domain (the shelf), the thinned 503 continental domain (the slope), the oceanic domain, a wide transitional zone and a domain called 504 the 'neck area'. We know now the 3D crustal geometry of the Armorican margin. A structural sketch 505 of the Armorican margin that summarizes the observations made is given in Fig. 15.

506 The main conclusions are as follows.

507 (1) The ocean-continent boundary, previously proposed to be a sharp contact, is in fact an ocean508 continent transition zone of $80 \mathrm{~km}$ width. This zone coincides with a major part of the Armorican 509 Basin. It shares the main characteristics of other ocean-continent transition zones: very quiet 510 magnetic signature, occurrence of shallow high-velocity material (the high-velocity lower-crustal 511 layer, 7.4-7.5 $\mathrm{km} \mathrm{s}^{-1}$ ) and of a subhorizontal basement surface that systematically overlies a 512 complex reflectivity zone including both the landward- and seaward-dipping reflectors. However, the 513 Armorican ocean-continent transition zone does show some distinctive features compared with 514 other ocean-continent transition zones. It is marked by the presence of Moho reflections beneath 515 the ocean-continent transition zone, the existence of volcanic bodies close to the oceanic domain 516 and by particularities of the high-velocity lower-crustal layer, which is overlain by the sediments. 517 Compared with the other non-volcanic passive North Atlantic margins (White 1992a, 1992b), the 518 oceanic crust immediately adjacent to the Biscay continent-ocean transition is thinner than the 519 normal oceanic crust. The high-velocity lower-crustal layer of the Armorican ocean-continent 520 transition zone could represent an abnormal mantle constituted by serpentinized peridotites.

521 (2) The North Biscay Ridge, as defined in the 1970s, does not exist along the North Biscay margin, 522 but instead is part of a large plateau situated off the North Armorican margin. This plateau may be 523 due to local underplating of the high-velocity lower-crustal layer under the oceanic crust.

524 (3) Continental crustal thinning is restricted to the narrow continental slope ( $15-50 \mathrm{~km}$ wide) with the 525 corollary that the contribution of crustal stretching was very limited. The new seismic profiles show 526 that the crustal thickness decreases under the continental slope from about $3.5 \mathrm{~km}$ at the shelf break 527 to less than $10 \mathrm{~km}$ at the foot of the slope. Crustal thinning is expressed along a major escarpment 528 in the upper continental crust superimposed on a steep shallowing of the mantle. We consider that 529 the continental slope represents, as a first approximation, the geometry of the initial continental 530 break-up.

531 (4) The S reflector and extensional structures such as tilted blocks are observed exclusively at the 532 base of the continental slope in the narrow domain called the 'neck area'. The Norgasis seismic 533 data show the following features. (a) A deep-layered crust is squeezed between the $S$ reflector and 
534 the Moho. It could be explained as a part of the thinned and stretched layered lower continental 535 crust or as a crust underplated or intruded during the rifting phase. (b) The S reflector has influence 536 restricted to the zone of tilted blocks. It seems to correspond to an intra-crustal detachment surface 537 of tilted blocks that evolves towards the ocean into an interface between faulted blocks and either 538 the deep-layered crust or the upper mantle. (c) The tilted blocks are considered to be gravity slide 539 structures. We conclude that the 'neck area' represents a 'glide block area'.

540 In comparison with other divergent margins, we consider that the Armorican margin is not atypical. 541 The Labrador, West Greenland, Orphan Basin, Southern Grand Banks, Nova Scotia and Flemish 542 Cap margins present some very similar features: they all have narrow continental slopes, which are 543 the loci of the main crustal thinning (see Keen \& Dehler 1997; Louden \& Chian 1999, p. 745; Fig. 1). 544 The crustal geometry of the Armorican margin (Fig. 15) can also be compared with the West Iberia 545 margin, which also exhibits a narrow continental slope linked to a sharp escarpment, and a high 546 upper mantle uprising as exemplified by the IAM 9 profile (Fig. 16).

547 This paper has examined only one segment of the North Biscay margin, the Armorican margin. The 548 geometry of the Armorican margin seems very different from the published structural interpretations 549 of the Western Approaches margin (Avedik \& Howard 1979; Montadert et al. 1979b). In contrast, the 550 Armorican margin has a wide ocean-continent transition zone and fewer tilted blocks.

551 Numerous questions remain: what are the geodynamic processes that permitted the creation of a 552 wide ocean-continent transition zone along the Armorican margin? Why are the two segments of 553 the North Biscay margin, the Western Approaches margin and the Armorican margin, so different?

\section{Acknowledgements}

555 The first author thanks J.-L. Olivet and D. Aslanian for their interest and help during the evolution of 556 this study, and Ifremer and Institut Universitaire Européen de la Mer (IUEM) for their support. We 557 are grateful to D. Needham, J. Girardeau and G. Cornen for critical reviews of the manuscript and 558 constructive discussions, and reviewers are gratefully acknowledged for their pertinent comments 559 helpful for the final manuscript. C. Truffert (BRGM) provided much appreciated help in the 560 processing of the magnetic data. R. Le Suavé and G. Auffret gave us free access to the data 561 collected during the Zee-Gascogne and Sédifan cruises, respectively.

\section{References}

563 Avedik, F., Howard, D. , ET AL., 1979. Preliminary results of a seismic refraction study in the Meriadzek-Trevelyan area, 564 Bay of Biscay. In: Montadert, L. \& Roberts, D.G. (eds) Initial Reports of Deep-Sea Drilling Project, 48. US Government 565 Printing Office, Washington, DC, 1015-1023.

566 Avedik, F., Camus, A.L., Ginzburg, A., Montadert, L., Roberts, D.G. \& Whitmarsh, R.B. 1982. A seismic refraction and 567 reflection study of the continent-ocean transition beneath the north Biscay margin. Philosophical Transactions of the 568 Royal Society of London, 305, 5-25.[CrossRef] 
Avedik, F., Renard, V., Allenou, J.P. \& Morvan, B. 1993. Single-bubble airgun array for deep exploration. Geophysics, 38,

Avedik, F., Hirn, A., Renard, V., Nicolich, R., Olivet, J.L. \& Sachpazi, M. 1996. 'Single-bubble' marine source offers new perspectives for lithospheric exploration. Tectonophysics, 267, 57-71.[CrossRef][Web of Science][GeoRef]

573 Bacon, M., Gray, F. \& Matthews, D.H. 1969. Crustal structure studies in the Bay of Biscay. Earth and Planetary Science 574 Letters, 6, 377-385.[Web of Science][GeoRef]

575 Barbier, F., Duvergé, J., Le Pichon, X. 1986. Structure profonde de la marge Nord Gascogne. Implications sur le mécanisme de rifting et de formation de la marge continentale. Bulletin du Comité de Recherche et de Production de la Société Nationale d'Elf Aquitaine, 10, 105-121.

Beslier, M.O., Girardeau, J. \& Boillot, G. 1988. Lithologie et structure des péridotites à plagioclases bordant la marge continentale passive de la Galice (Espagne). Comptes Rendus de l'Académie des Sciences, 306, 373-380.

580 Boillot, G., Grimaud, S., Mauffret, A., Mougenot, D., Kornprobst, J., Mergoil-Daniel, J. \& Torrent, G. 1980. Ocean581 continent boundary off the Iberian margin: a serpentinite diapir west of the Galicia Bank. Earth and Planetary Science Letters, 48, 23-34.[CrossRef][Web of Science][GeoRef]

Boillot, G., Recq, M. , ET AL., 1987a. Tectonic denudation of the upper mantle along passive margins: a model based on 585 drilling results (ODP Leg 103, W. Galicia margin, Spain). Tectonophysics, 132, 3:35-342.[CrossRef][Web of Science][GeoRef]

Boillot, G., Winterer, E. L., Meyer, A. W., et al. (eds) 1987b Proceedings of the Ocean Drilling Program, Initial Reports, 103. Ocean Drilling Program, College Station, TX.

Boillot, G., Girardeau, J., Kornprobst, J. et al. 1988. Rifting of the Galicia margin: crustal thinning and emplacement of mantle rocks on the seafloor. In: Boillot, G. \& Winterer, E.L. (eds) Proceedings of the Ocean Drilling Program, Scientific Results, 103. Ocean Drilling Program, College Station, TX, 741-756.

Boillot, G., Mougenot, D., Girardeau, J. \& Winterer, E.L. 1989. Rifting processes on the West Galicia margin, Spain. In: Tankard, A.J. \& Balkwill, H.R. (eds) Extensional Tectonics and Stratigraphy of the North Atlantic Margins. American Association of Petroleum Geologists Memoir, 46, 353-355.

Boillot, G., Beslier, M.O., Krawczyk, C.M., Rappin, D. \& Reston, T.J. 1995. The formation of passive margins: constraints from the crustal structure and segmentation of the deep Galicia margin, Spain. In: Scrutton, R.A., Stoker, M.S., Shimmield, G.B. \& Tudhope, A.W. (eds) The Tectonics, Sedimentation and Palaeoceanography of the North Atlantic Region. Geological Society, London, Special Publications, 90, 71-91.

Cazes, M., Bois, Ch. \& Damotte, B. 1988. Principales Acquisitions Scientifiques ou Intérêt Industriel. Programme ECORS. Institut Français du Pétrole, Institut National des Sciences de I'Univers, CNRS et SNEA, Paris, 1, 223-249. volcanic margin. Journal of the Geological Society. London, 154, 571-576.[Abstract/Free Full Text][CrossRef][Web of Science][GeoRef] 
Chian, D. \& Louden, K.E. 1994. The continent-ocean crustal transition across the southwest Greenland margin. Journal of 608 Geophysical Research, 99, 9117-9135.[CrossRef][GeoRef]

609 Chian, D., Louden, K.E. \& Reid, I. 1995. Crustal structure of the Labrador Sea conjugate margin and implications for the 610 formation of non-volcanic continental margins. Journal of Geophysical Research, 100, 24239-24253.[CrossRef]

611 Chian, D., Louden, K.E., Minshull, T.A. \& Whitmarsh, R.B. 1999. Deep structure of the ocean-continent transition in the 612 southern Iberia Abyssal Plain from seismic refraction profiles: Ocean Drilling Program (Legs 149 and 173) transect. 613 Journal of Geophysical Research, 104, 7443-7462.[CrossRef][GeoRef]

614 Cornen, G., Beslier, M.O. \& Girardeau, J. 1996. Petrologic characteristics of the ultramafic rocks from the ocean/continent 615 transition in the Iberia Abyssal Plain. In: Whitmarsh, R.B., Sawyer, D.S., Klaus, A. \& Masson, D.G. (eds) Proceedings of 616 the Ocean Drilling Program, Scientific Results, 149. Ocean Drilling Program, College Station, TX, 377-396.

617 Cornen, G., Girardeau, J. \& Monnier, C. 1999. Basalts, underplated gabbros and pyroxenites record the rifting process of 618 the West Iberian margin. Mineralogy and Petrology, 67, 111-142.[CrossRef][Web of Science][GeoRef]

619 Debyser, J., Le Pichon, X. \& Montadert, L. (eds) 1971 Histoire Structurale du Golfe de Gascogne. Publication de I'Institut 620 Français du Pétrole, I et II.

621 de Charpal, O., Guennoc, P., Montadert, L. \& Roberts, D.G. 1978. Rifting, crustal attenuation and subsidence in the Bay of 622 Biscay. Nature, 275, 706-711.[CrossRef][Web of Science]

623 de Graciansky, P. C., Paog, C. W., et al. (eds) 1985 Initial Reports of the Deep Sea Drilling Project, 80. US Government 624 Printing Office, Washington, DC.

625 Derégnaucourt, D. \& Boillot, G. 1982. Structure géologique du golfe de Gascogne. Bulletin du BRGM, 1, $149-178$.

626 Dyment, J., 1989. SWAT et les bassins celtiques: relations avec la croûte hercynienne, néoformation du Moho. Bulletin de 627 la Société Géologique de France, 8, 477-487.

628 Frappa, M. \& Vaillant, F.X. 1972. Prolongation vers l'ouest des structures du golfe de Gascagne. Bulletin de I'Institut de 629 Géologie du Bassin d'Aquitaine, 12, 101-121.

630 Ginzburg, A., Whitmarsh, R.B., Roberts, D.G., Montadert, L., Camus, A. \& Avedik, F. 1985. The deep seismic structure of 631 the northern continental margin of the Bay of Biscay. Annales Geophysicae, 3, 499-510.[GeoRef]

632 Girardeau, J., Evans, C.A. \& Beslier, M.O. 1988. Structural analysis of plagioclase-bearing peridotites emplaced at the end 633 of continental rifting: hole 637A, ODP LEG 103 on the Galicia margin. In: Mazzullo, E.K. (ed.) Proceeding of the Ocean 634 Drilling Program, Scientific Results, 103. Ocean Drilling Program, College Station, TX, 209-223.

635 Girardeau, J., Cornen, G. et al. 1998. Premiers résultats des plongées du Nautile sur le Banc de Gorringe (Ouest 636 Portugal). Comptes Rendus de l'Académie des Sciences, 326, 247-254.

637 Grau, G., Montadert, L., Delteil, R. \& Winnock, E. 1973. Structure of the European continental margin between Portugal 638 and Ireland, from seismic data. Tectonophysics, 20, 319-339.[CrossRef][Web of Science][GeoRef]

639 Kanasawa, T. \& Shiobara, H. 1994. New ocean bottom seismometer system for a dense survey. Abstracts, Japan Earth 640 and Planetary Science Joint Meeting./11, P82-341.

641 Keen, C.E. \& Dehler, S.A. 1997. Extensional styles and gravity anomalies at rifted continental margins: some North 642 Atlantic examples. Tectonics, 16, 744-754.[CrossRef][Web of Science][GeoRef] 
Keen, C.E., De Voogd, B. 1988. The continent-ocean boundary at the rifted margin off eastern Canada: new results from deep seismic reflection studies. Tectonics, 7, 107-124.[CrossRef][Web of Science]

645 Le Borgne, E., Le Mouël, J.L. 1970. Cartographie aéromagnétique du Golfe de Gascorgne. Comptes Rendus de 646 l'Académie des Sciences, 271, 1167-1170.

647 Le Pichon, X. \& Barbier, F. 1987. Passive margin formation by low-angle faulting within the upper crust: the northern Bay 648 of Biscay margin. Tectonics, 6, 133-150.[Web of Science][GeoRef]

649 Le Pichon, X. \& Sibuet, J.C. 1981. Passive margins: a model of formation. Journal of Geophysical Research, 86, 3708650 3720.[GeoRef]

651 Limond, W.Q., Gray, F., Grau, G., Fail, J.P., Montadert, L., Patriat, Ph. 1974. A seismic study in the Bay of Biscay. Earth 652 and Planetary Science Letters, 23, 357-358.[CrossRef][Web of Science][GeoRef]

653 Louden, K.E. \& Chian, D. 1999. The deep structure off non-volcanic rifted continental margins. Philosophical Transactions 654 of the Royal Society of London, 357, 767-805.

655 Ludwig, W.J., Nafe, J.E. \& Drake, C.L. 1970. Seismic refraction. In: Maxwell, A.E. (ed.) The Sea. Publisher, New York, $656 \quad 53-84$.

657 Manatschal, G. \& Nievergelt, P. 1997. A continent-ocean transition recorded in the Err and Platta nappes (Eastern 658 Switzerland). Eclogae Geologicae Helvetiae, 90, 3-27.[Web of Science]

659 Montadert, L., 1984. Segmentation morphologique et structurale. In: Boillot, G., Montadert, L., Lemoine, M., Biju-Duval, B. 660 (eds) Les Marges Continentales Actuelles et Fossiles autour de la France. Masson, Paris, 82-121.

661 Montadert, L., Damotte, B., Fail, J.P., Delteil, J.R. \& Valery, P. 1971. Structure géologique de la plaine abyssale du Golfe 662 de Gascogne. In: Debyser, J., Le Pichon, X. \& Montadert, L. (eds) Histoire Structurale du Golfe de Gascogne. IFP663 CNEXO, Paris, II, VI.14.1-VI.14.42.

664 Montadert, L., Winnock, E., Delteil, J.R. \& Grau, M. 1974. Continental margins of Galicia-Portugal and Bay of Biscay. In: 665 Burk, C.A. \& Drake, C.L. (eds) Publisher, Town, 323-341.

666 Montadert, L., Roberts, D. G., et al. (eds) 1979a Initial Reports of the Deep Sea Drilling Project, 48. US Government 667 Printing Office, Washington, DC.

668 Montadert, L., Roberts, D.G., De Charpal, O., Guennoc, P. 1979b. Rifting and subsidence of the northern continental 669 margin of the Bay of Biscay. In: Montadert, L., Roberts, D.G. et al. (eds) Initial Reports of the Deep Sea Drilling Project, 670 48. US Government Printing Offic, Washington, DC, 1025-1060.

671 Nicholls, I.A., Ferguson, J., Jones, H., Marks, G.P. \& Mutter, J.C. 1981. Ultramafic blocks from the ocean floor southwest 672 of Australia. Earth and Planetary Science Letters, 56, 362-374.[CrossRef][Web of Science][GeoRef]

673 Olivet, J.L., 1996. La cinématique de la plaque ibérique. Bulletin du Centre de Recherches Exploration-Production Elf674 Aquitaine, 20, 131-195.

675 Pickup, S.L.B., Whitmarsh, R.B., Fowler, C.M.R. \& Reston, T.J. 1996. Insight into the nature of the ocean-continent 676 transition off West Iberia from a deep multichannel seismic reflection profile. Geology, 24, 1079677 1082.[Abstract/Free Full Text][CrossRef][Web of Science][GeoRef] 
Pinheiro, L.M., Whitmarsh, R.B. \& Miles, P.R. 1992. The ocean-continent boundary off the western continental margin of Iberia-II. Crustal structure in the Tagus Abyssal Plain. Geophysical Journal International, 109, 106-124.[Web of 680 Science][GeoRef]

681 Recq, M., Whitmarsh, R.B., Sibuet, J.C., White, R.S. \& Lyness, D. 1996. Structure sismiquie de la ride de péridotite à l'ouest du Banc de Galice (Ouest Ibérie). Comptes Rendus de l'Académie des Sciences, 322, 571-578.

Reid, I., 1994. Crustal structure of a non-volcanic rifted margin east of Newfoundland. Journal of Geophysical Research, 99, 15161-15180.[CrossRef]

Reston, T.J., 1996. The S reflector west of Galicia: the seismic signature of a detachment fault. Geophysical Journal International, 127, 230-244.[Web of Science][GeoRef]

Reston, T.J., Krawczyk, C.M. \& Klaeschen, D. 1996. The S reflector west of Galicia (Spain): evidence from pre-stack depth migration for detachment faulting during continental break-up. Journal of Geophysical Research, 101, 80758091.[CrossRef][GeoRef]

Sawyer, D. S., Whitmarsh, R. B., Klaus, A., et al. (eds) 1994 Proceeding of the Ocean Drilling Program, Initial Reports, 149. Ocean Drilling Program, College Station, $T X$.

Sibuet, J.C., 1992. New constraints on the formation of the non-volcanic continental Galicia-Flemish Cap conjugate margins. Journal of the Geological Society. London, 149, 829-840.[Abstract/Free Full Text][CrossRef][Web of Science][GeoRef]

Sibuet, J.C., Louvel, V. \& Dyment, J. 1992. Crustal structure of the Celtic Sea basins and Goban Spur margin (NW Europe) from gravity data and deep seismic profiles: constraints on the formation of continental basins and margins. Trends in Geophysical Research, Research Trends, Sreekanteswaram, Trivadrum, India, 1, 173-201.

698 Sibuet, J.C., Monti, S. \& Pautot, G. 1994. New bathymetric map of the Bay of Biscay. Comptes Rendus de l'Académie des 699 Sciences, 318, 615-625.

700 Sibuet, J.C., Pautot, G., Le Pichon, X. 1971. Interprétation structurale du Golfe de Gascagne à partir des profils de 701 sismique. In: Debyser, J., Le Pichon, X. \& Montadert, L. (eds) Histoire Structurale du Golfe die Gascogne. Publication de 702 I'Institut Français du Pétrole, II, VI.10.1-VI.10.31.

703 Skogseid, J., Pedersen, T. \& Larsen, V.B. 1992. Vöring Basin: subsidence and tectonic ewolution. In: Larsen, R.M. \& 704 Talleraas, E. (eds) Structural and Tectonic Modelling and its Application to Petroleum Geology. Norwegian Petroleum 705 Society Special Publication, 1, 55-82.

706 Srivastava, S.P., Roest, W.R. 1995. Nature of thin crust across the Southwest Greenland margin and its bearing on the 707 location of the ocean-continent boundary. In: Banda, E. et al. (eds) Rifted Ocean-Continent Boundaries. Publisher, Town, $70895-120$.

709 Srivastava, S.P., Sibuet, J.C., Cande, S., Roest, W.R. \& Reid, I.D. 2000. Magnetic evidence for slow seafloor spreading 710 during the formation of the Newfoundland and Iberian margins. Earth and Planetary Science Letters, 182, 61711 76.[CrossRef][Web of Science][GeoRef]

712 Thinon, I. 1999 Structure profonde de la marge Nord Gascogne et du bassin Armoricain (golfe de Gascogne). PhD thesis, 713 Brest University. 
Thinon, I., Fidalgo-González, L., Réhault, J.P. \& Olivet, J.L. 2001. Pyrenean deformation in the northern Bay of Biscay. Comptes Rendus de l'Académie des Sciences, 332(9), 561-568.

Thinon, I., Réhault, J.P., Fidalgo-González, L. 2002. La Couverture Sédimentaire Syn-rift de lla Marge Nord Gascogne et du Bassin Armoricain (Golfe de Gascogne) à Partir de Nouvelles Données de Sismique Réflexion. Bulletin de la Société Géologique de France, 273, in press.

Vaillant, X. 1988 L'extrémité de la marge Nord Gascogne: contexte stratigraphique, structural et cinématique. Implications géodynamiques. PhD thesis, Brest University.

Verhoef, J., Roest, W. R., Macnab, R., Arkani-Hamed, J. \& Members of the Project Team, 1996 Magnetic Anomalies of the Arctic and North Atlantic Oceans and Adjacent Land Areas. Geological Survey of Canada.

White, R.S., 1992a. Crustal structure and magmatism of North Atlantic continental margins. Journal of the Geological Society, London, 149, 841-854.[Abstract/Free Full Text][CrossRef][Web of Science][GeoRef]

White, R.S., 1992b. Magmatism during and after continental break-up. In: Storey, B.C., Alabaster, T. \& Pankhurst, R.J. (eds) Magmatism and the Causes of Continental Break-up. Geological Society, London, Special Publications, 68, 1-16.

Whitmarsh, R.B. \& Miles, P.R. 1995. Models of the development of the West Iberia rifted continental margin at $40^{\circ} 30^{\prime} \mathrm{N}$ deduced from surface and deep-tow magnetic anomalies. Journal of Geophysical Research, 100, 37893806.[CrossRef][GeoRef]

Whitmarsh, R.B., Miles, P.R. \& Mauffret, A. 1990. The ocean-continent boundary off the western continental margin of Iberia-I. Crustal structure at $40^{\circ} 30^{\prime} \mathrm{N}$. Geophysical Journal International, 103, 509-531.[Web of Science][GeoRef]

Whitmarsh, R.B., Avedik, F. \& Saunders, M.R. 1986. The seismic structure of thinned continental crust in the northern Bay of Biscay. Geophysical Journal of the Royal Astronomical Society, 86, 589-602.[Web of Science][GeoRef]

Whitmarsh, R.B., Sawyer, D.S. , ET AL., 1996. The ocean/continent transition beneath the Iberia Abyssal Plain and continental-rifting to seafloor-spreading processes. In: Sawyer, D.S., Whitmarsh, R.B. \& Klaus, A. (eds) Proceedings of the Ocean Drilling Program, Initial Reports, 149. Ocean Drilling Program, College Station, TX, 713-733.

Whitmarsh, R. B., Beslier, M. O., Wallace, P. J., et al. (eds) 1998 Proceeding of the Ocean Drilling Program, Initial Reports, 173. Ocean Drilling Program, College Station, $T X$.

Whitmarsh, R.B., Manatschal, G. \& Minshull, T.A. 2001. Evolution of magma-poor continental margins from final rifting to seafloor spreading. Nature, 413, 150-154.[CrossRef][GeoRef]

Williams, C.A., 1975. Sea-floor spreading in the Bay of Biscay and its relationship to the North Atlantic. Earth and Planetary Science Letters, 24, 440-456.[CrossRef][Web of Science][GeoRef]

Zelt, C.A. \& Ellis, R.M. 1988. Practical and efficient ray tracing in two-dimensional media for rapid travel time and amplitude forward modelling. Canadian Journal of Exploration Geophysics, 24, 16-34.[GeoRef] International, 108, 16-31.[Web of Science][GeoRef] 


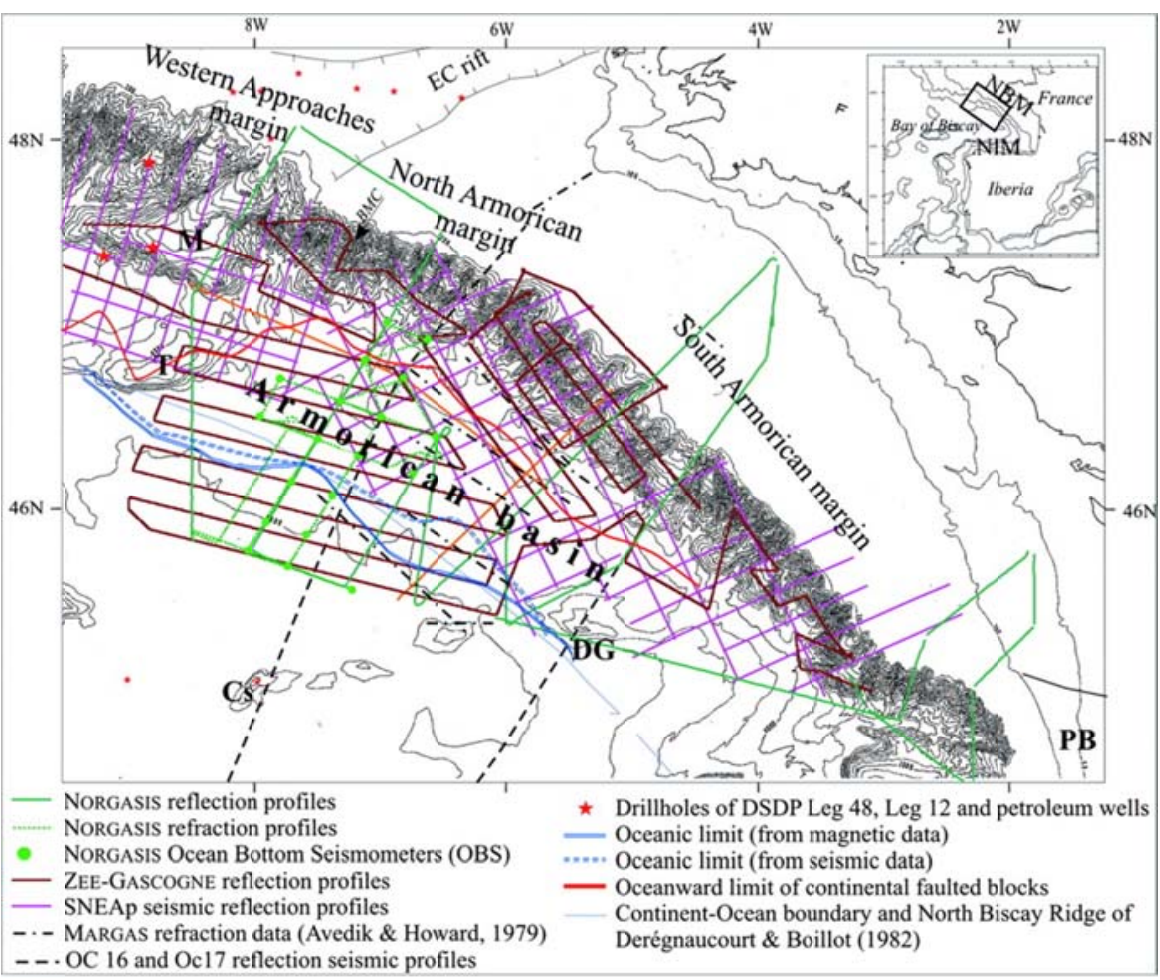

Fig. 1. Bay of Biscay seismic survey location map. Isobath interval of the bathymetry (Sibuet et al. 1994) is 200 m. Mercator projection 1/2 400000 at $41^{\circ} \mathrm{N}$ latitude, showing locations of the deep drillholes (Deep Sea Drilling Program (DSDP); petroleum). PB, Parentis Basin; M, Meriadzek Terrace; T, Trevelyan Seamount; BMC, Black Mud Canyon; Cs, Cantabria Seamount; DG, Dôme Gascogne; EC rift, English Channel Rift; NBM, North Biscay margin; NIM, North Iberia margin

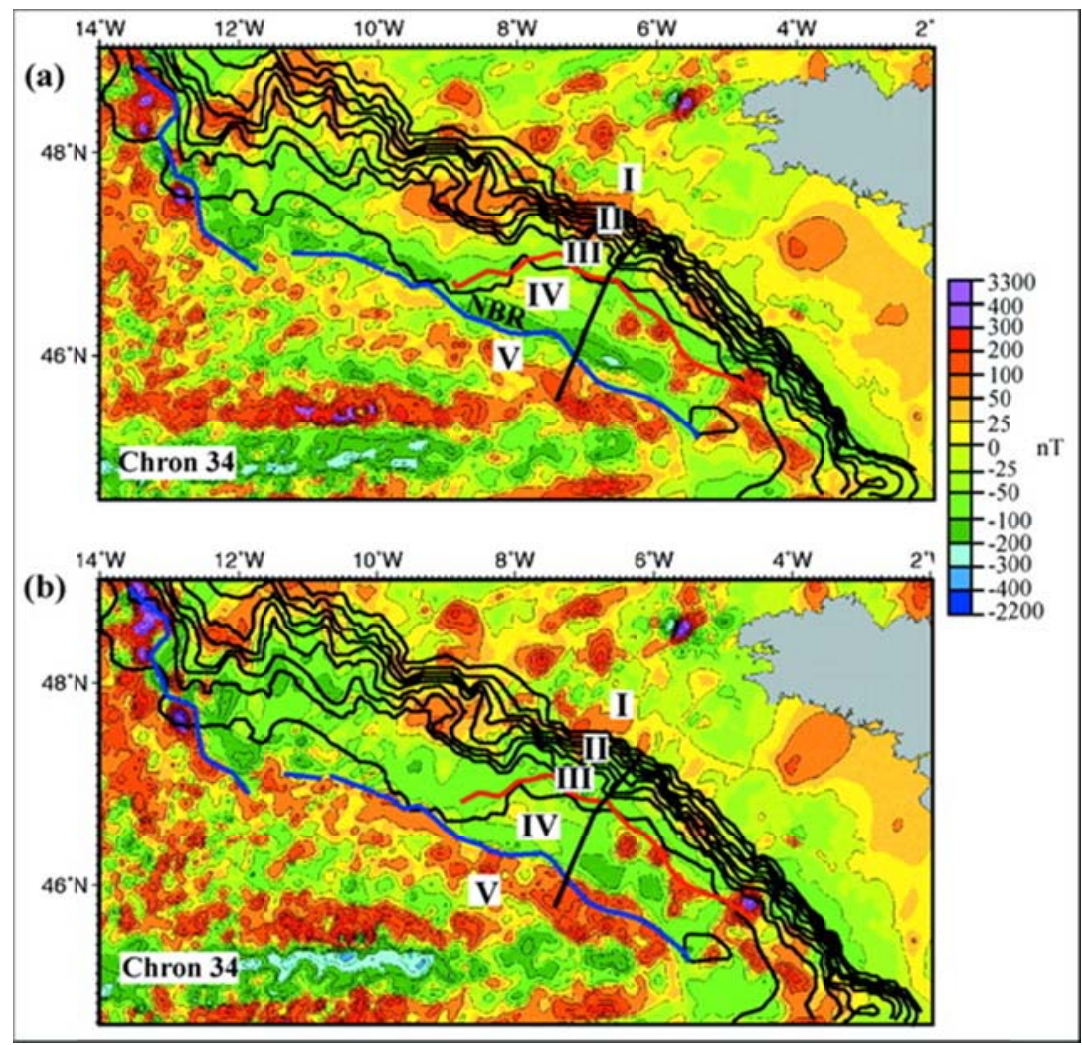

Fig. 2. (a) Map of the total field magnetic anomalies (numerical magnetic data collected by Verhoef et al. 1996). (b) Map of the magnetic anomalies reduced to pole, from the total field magnetic data of Verhoef et al. (1996). The pole reduction of magnetic data has been made with surfer and gmipack software in collaboration with BRGM (Orléans, France). The structural zones (blue line, oceanic limit from seismic data; red line, limit of 
the last continental blocks) and the OC17 seismic reflection profiles are reported here. I, continental shelf; II, continental slope; III, 'neck area'; IV, ocean-continent transition zone; V, true oceanic domain; NBR, North Biscay Ridge.

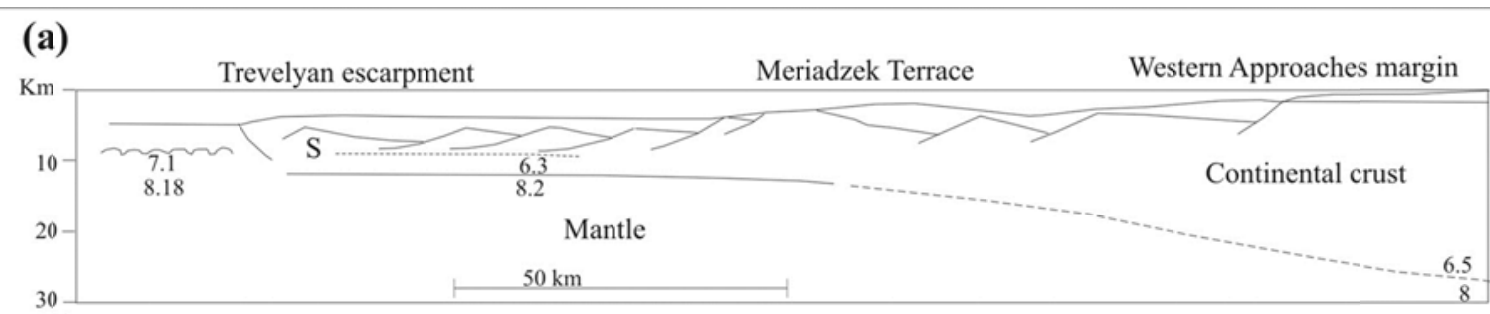

(b)

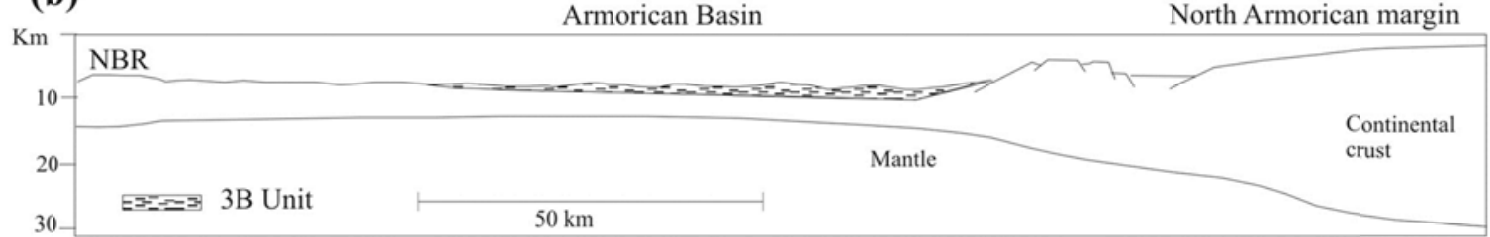

(C)
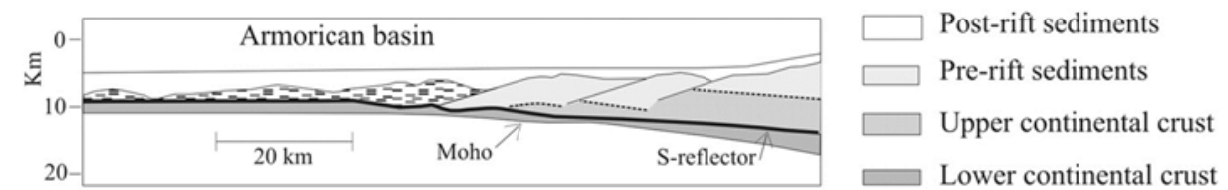

Fig. 3. Published structural schema of the North Biscay margin. (a) The Western Approaches margin from Avedik \& Howard (1979) and Montadert et al. (1979). (b) The Armorican margin from Le Pichon \& Sibuet (1981). NBR, North Biscay Ridge. (c) The Armorican margin from Barbier et al. (1986) and Le Pichon \& Barbier (1987).

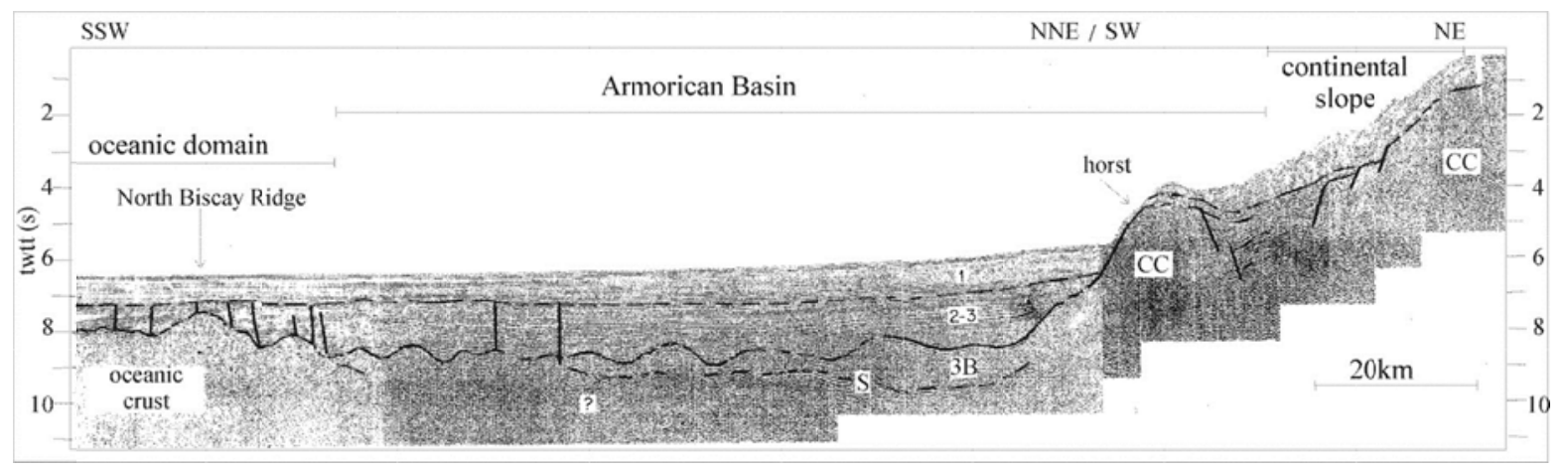

Fig. 4. OC17 seismic profile (for location, see Fig. 6) from Debyser et al. (1971). CC, Continental crust; $S$, S reflector; $3 B$, enigmatic unit; 1,2 and 3 are post-rift sediments. 

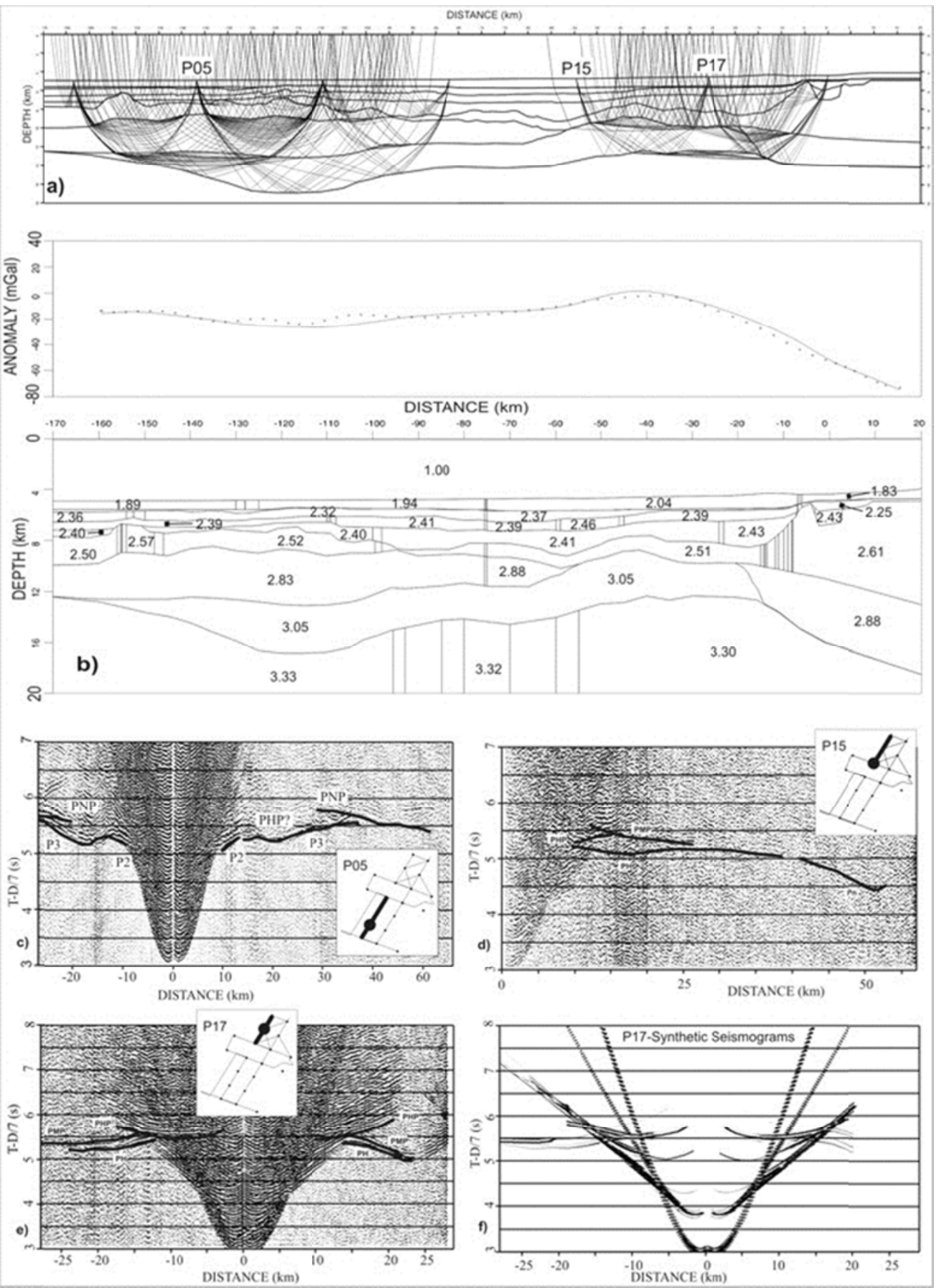

Fig. 5. (a) Structural model for profile Norgasis 14 with the ray paths that were used to define the deeper layers (only one ray in every four is plotted). The velocities (see Fig. 7b) and depths are constrained by reflected and diving waves. (b) Observed () and computed free-air gravity for the Norgasis 14 profile after transformation of P-wave velocities to density using the data from Ludwig et al. (1970). To improve the fit the model geometry was slightly modified in the unconstrained part near the coast and the density of the high-velocity lower-crustal layer above normal mantle was reduced. To account for lateral velocity or density variations within the same layer, the model is divided into blocks separated by vertical boundaries. The large number of these blocks is the consequence of strong heterogeneity. (c), (d) and (e) show examples of seismic refraction data for ocean-bottom seismometers P05, P15 and P17, respectively, plotted with $7 \mathrm{~km}$ s reduction velocity. An offsetdependent gain and a bandpass filter $(6-18 \mathrm{~Hz})$ have been applied. The computed travel times for the interpreted phases are overlain. Interpreted phases: P2, refracted arrival from oceanic layer 2; P3, refracted arrival from oceanic layer 3; PHP, reflected arrival from the top of the high-velocity lower-crustal layer; PH, refracted arrival from the high-velocity lower-crustal layer; PMP, reflected arrival from the Moho; Pn, refracted arrival from the top of normal mantle. (f) Synthetic seismograms computed by asymptotic ray theory for the P17 ocean-bottom seismometer, using a Ricker wavelet as source function. Same gain and plotting parameters as for the data section were used. 


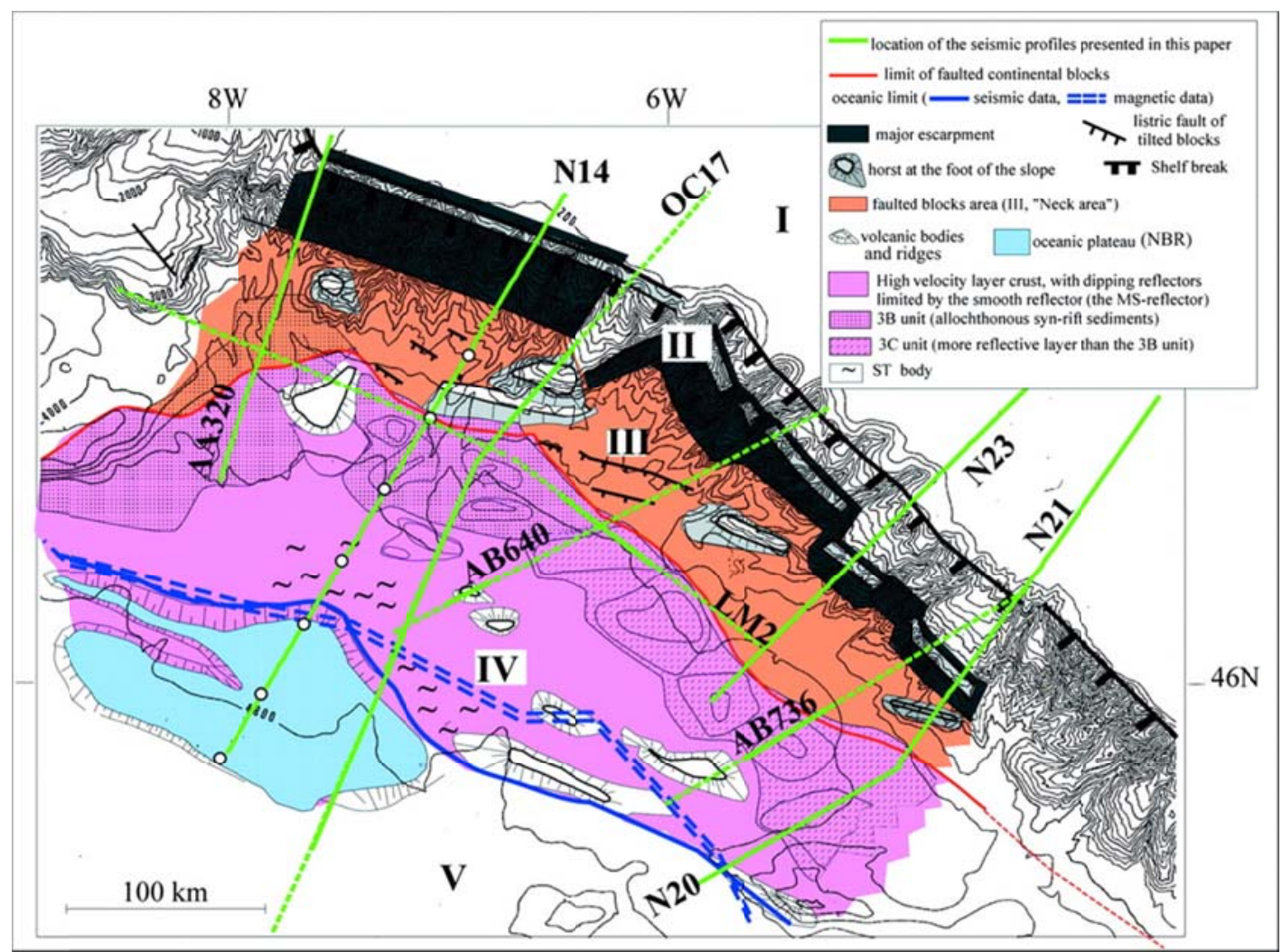

Fig. 6. Structural map of the Armorican margin. The location of cross-section (green line) included as figures is shown. ०, ocean bottom seismometers used for the refraction models along the Norgasis 14 profile.

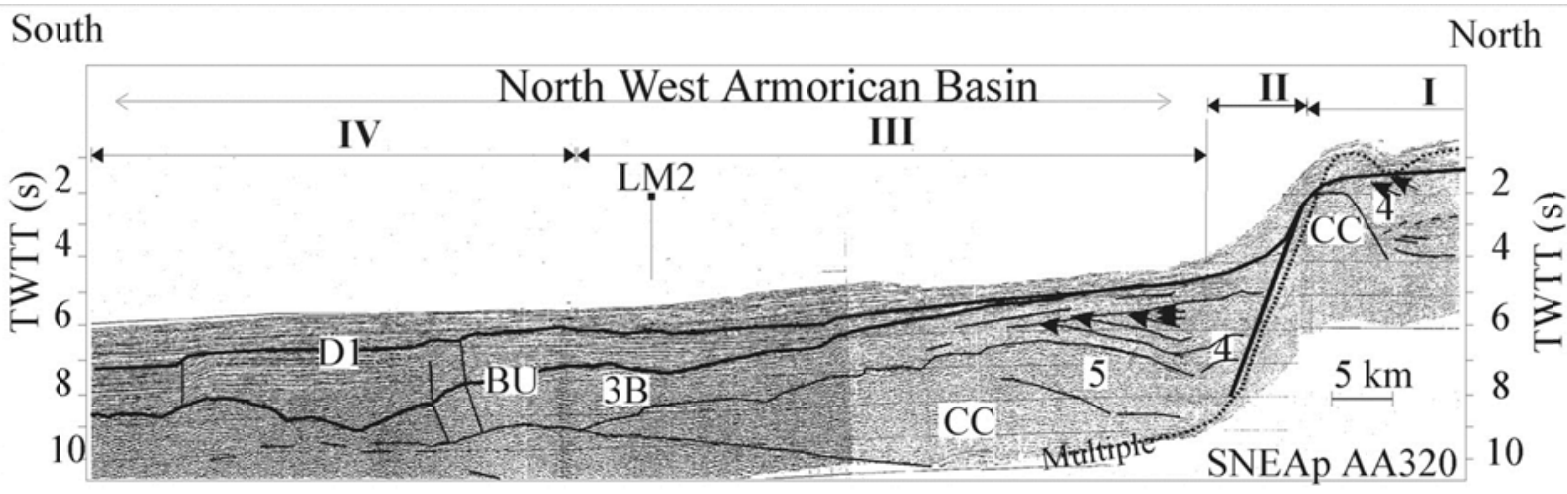

D1: Eocene Pyrenean unconformity; BU: break-up unconformity; 3B: allochthonous syn-rift unit; 4: autochthonous syn-rift unit; 5: pre-rift unit; $\mathrm{CC}$ : continental crust

Fig. 9. Stacked SNEAp reflection profile (for location see Fig. 6) across the North Armorican margin. A faulted block, composed of the upper continental crust (CC) and a thick pre-rift unit (5), is tilted at the base of a major escarpment that defines the continental slope. Unit 3B covers the autochthonous synrift unit (4), the continental blocks and the basement of ocean-continent transition zone. The intersection with the Loire Maritime 2 profile (LM2) is reported here. 3B, Allochthonous synrift unit; BU, break-up unconformity; D1, Pyrenean unconformity. 

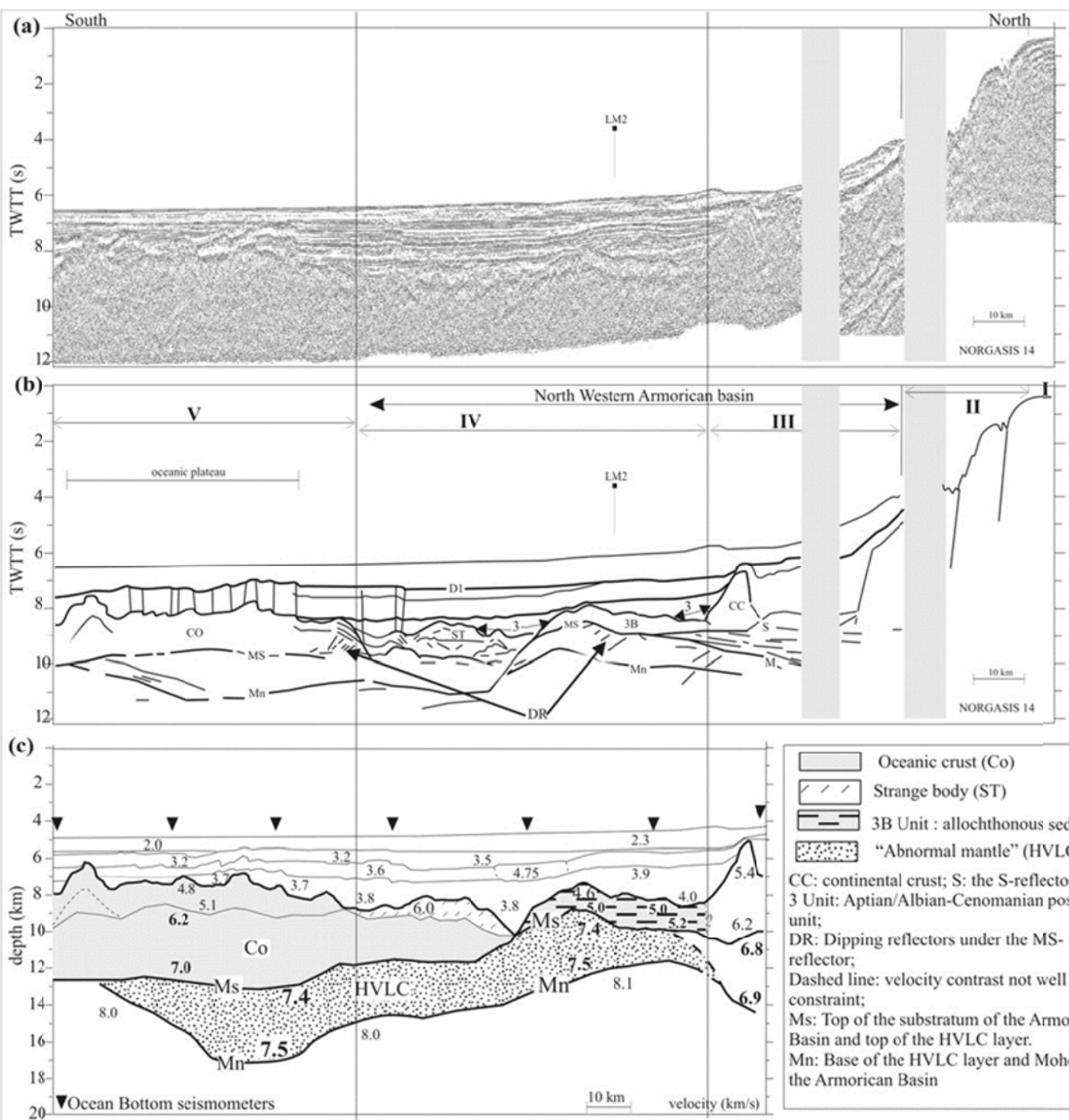

Oceanic crust (Co)
Strange body (ST)
CC: continental crust; S: the S-reflector;
3 Unit: Aptian/Albian-Cenomanian post-rift
unit;
DR: Dipping reflectors under the MS-
reflector;
Dashed line: velocity contrast not well
constraint;
Ms: Top of the substratum of the Armorican
Basin and top of the HVLC layer.
Mn: Base of the HVLC layer and Moho of
the Armorican Basin

Fig. 7. (a) Time-migrated reflection profile (Norgasis 14) across the North Armorican margin from the shelf to the oceanic domain across the ocean-continent transition zone; (b) line drawing of this profile; (c) refraction model computed by L. Matias and A. Hirn from Norgasis ocean-bottom seismometer data along the Norgasis 14 reflection profile (for location see Fig. 6). The intersection with the Loire Maritime 2 (LM2) profile is reported here. D1, Pyrenean unconformity (Eocene time); M, Moho reflections. 

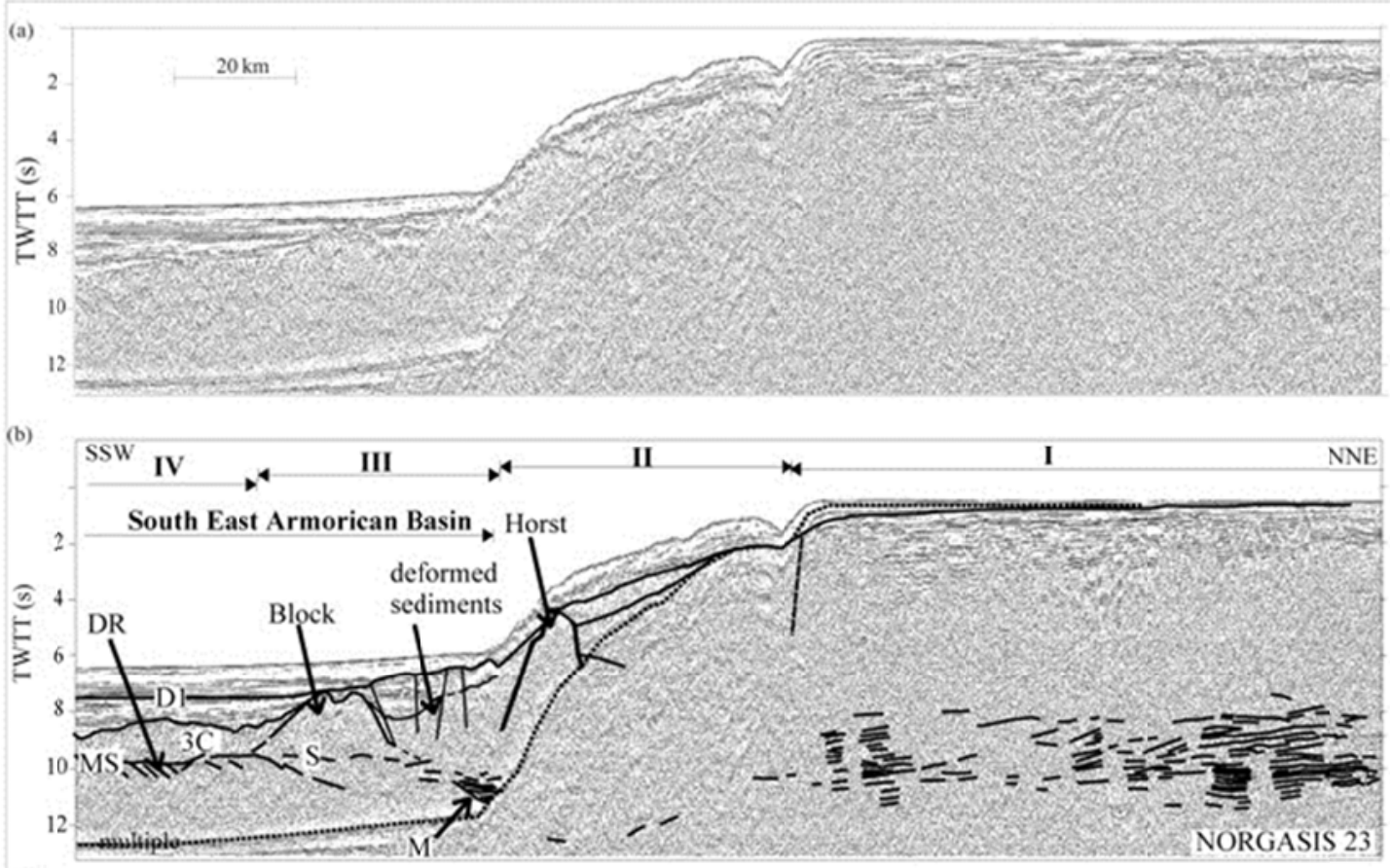

(c)

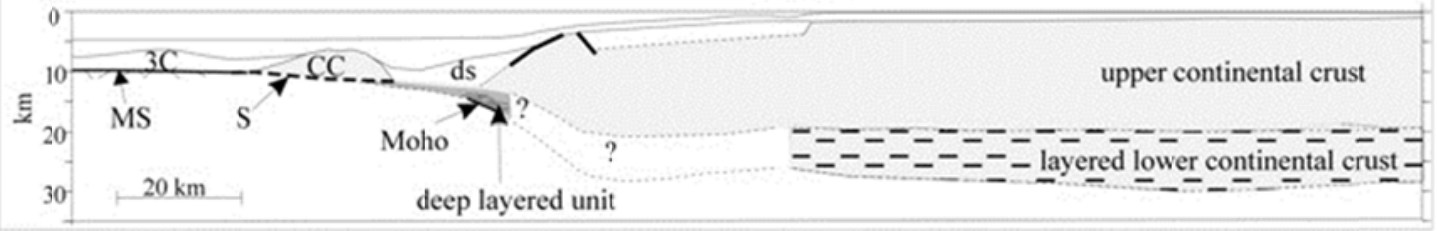

Fig. 8. (a) Time-migrated reflection profile (Norgasis 23; for location see Fig. 6) across the South Armorican margin; (b) interpreted profile; (c) synthetic depth section without vertical exaggeration. D1, Pyrenean unconformity; MS, basement of the OCT zone; DR, dipping reflectors; S, S reflector; M. Moho reflections; $3 C$, enigmatic seismic unit; CC, continental crust; ds, deformed sediments.

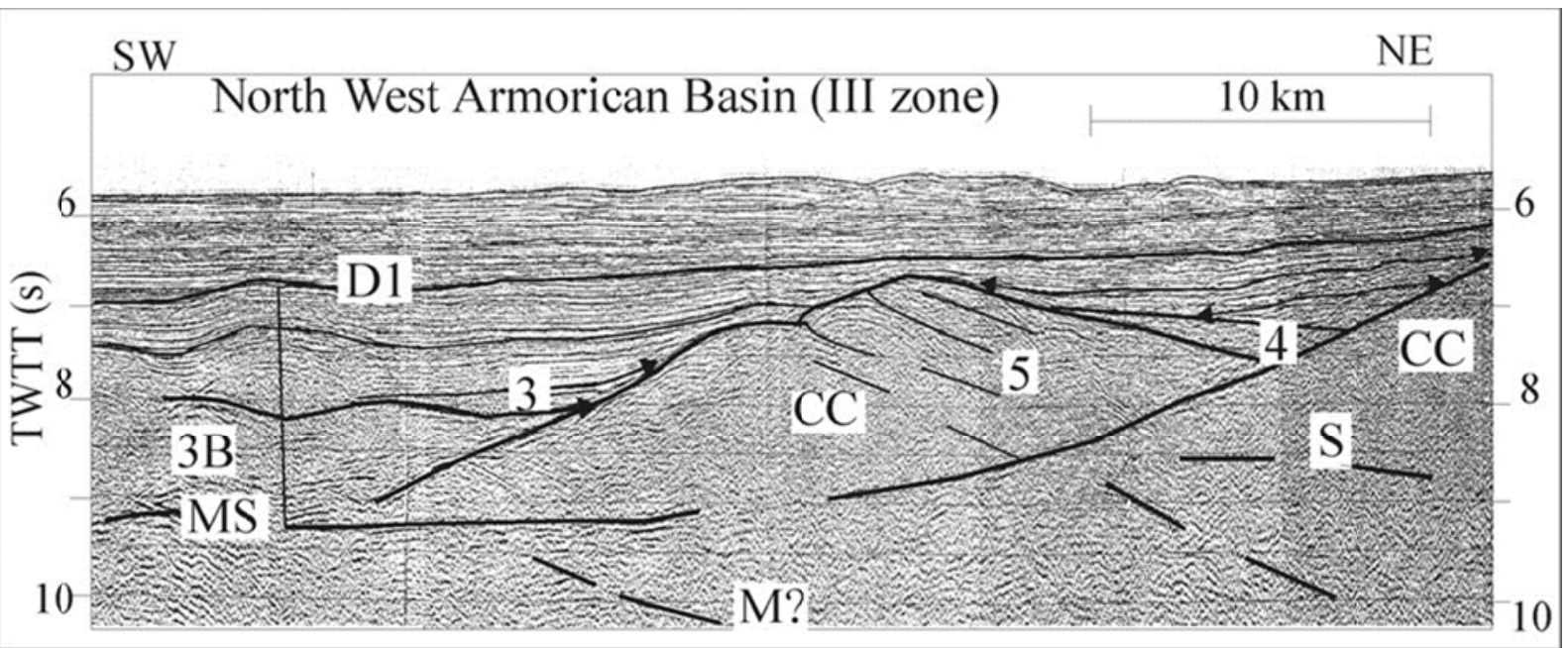

Fig. 10. Section of stacked AB640 SNEAp reflection profile (for location see Fig. 6) across the Armorican 'neck area'. 3B, Allochthonous synrift unit; D1, Pyrenean unconformity; 3, post-rift sediments; 4, synrift sediments; 5, pre-rift sediments; MS, basement of the ocean-continent transition zone; S, S reflector; M, Moho reflections; CC, continental crust 


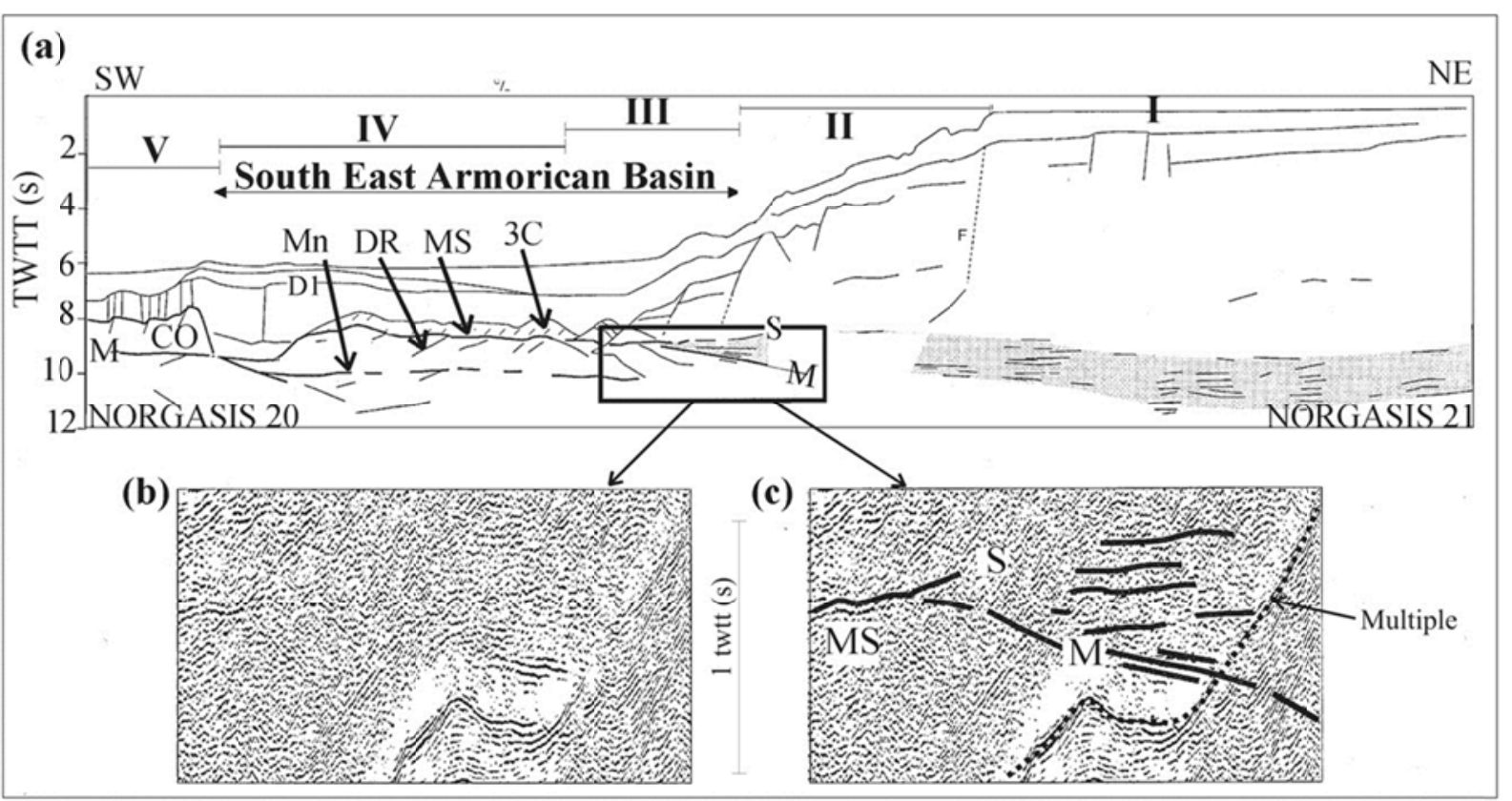

Fig. 11. (a) Line drawing of time-migrated reflection profiles (Norgasis $N 20$ and N21; for location see Fig. 6) across the South Armorican margin; (b) enlargement showing the deep layered unit and the relationships between the S, MS and M reflectors; (c) interpretation of the enlargement. D1, Pyrenean unconformity; MS, basement of the ocean-continent transition zone; $S$, $S$ reflector; $M$, Moho reflections; $D R$, dipping reflectors; $M n$, top of the normal mantle; $3 C$, enigmatic seismic unit; CC, continental crust; CO, oceanic crust.

(a)

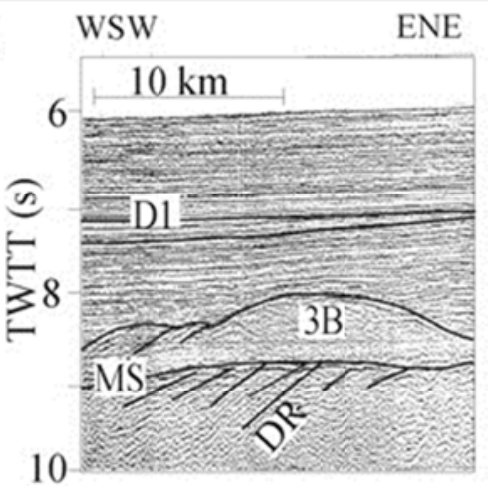

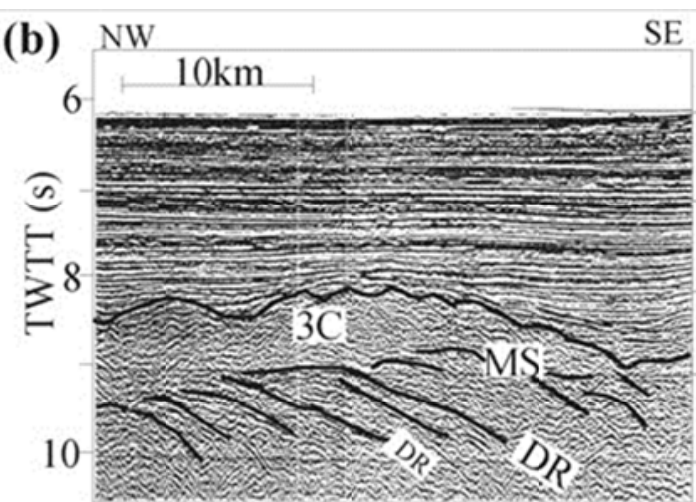

(c) W Armorican Basin (IV zone)

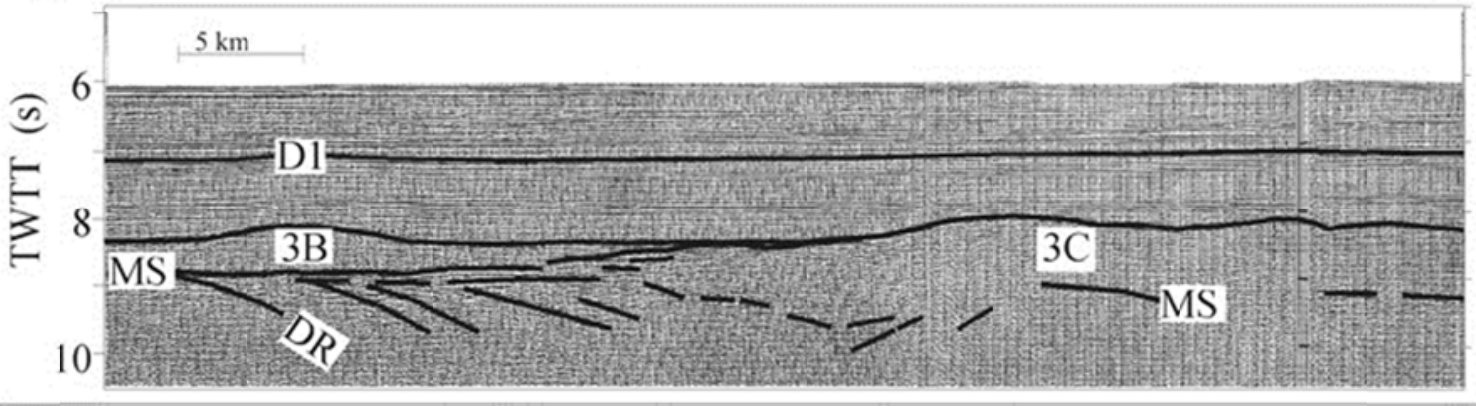

Fig. 12. (a) Enlargement of SNEA profile (for location see Fig. 6) showing the typical seismic character of the western Armorican ocean-continent transition zone (Fig. 7). Unit 3B covers the MS reflector, which truncates the dipping reflectors beneath. (b) Enlargement of SNEA profile (for location see Fig. 6) showing the different seismic character of Unit $3 C$ observed only in the eastern Armorican ocean-continent transition zone (Fig. 6). (c) Interpreted sections of Loire Maritime 2 profile (LM2). 3B, allochthonous synrift unit; D1, Pyrenean unconformity; MS, basement of the ocean-continent transition zone; DR, dipping reflectors. 


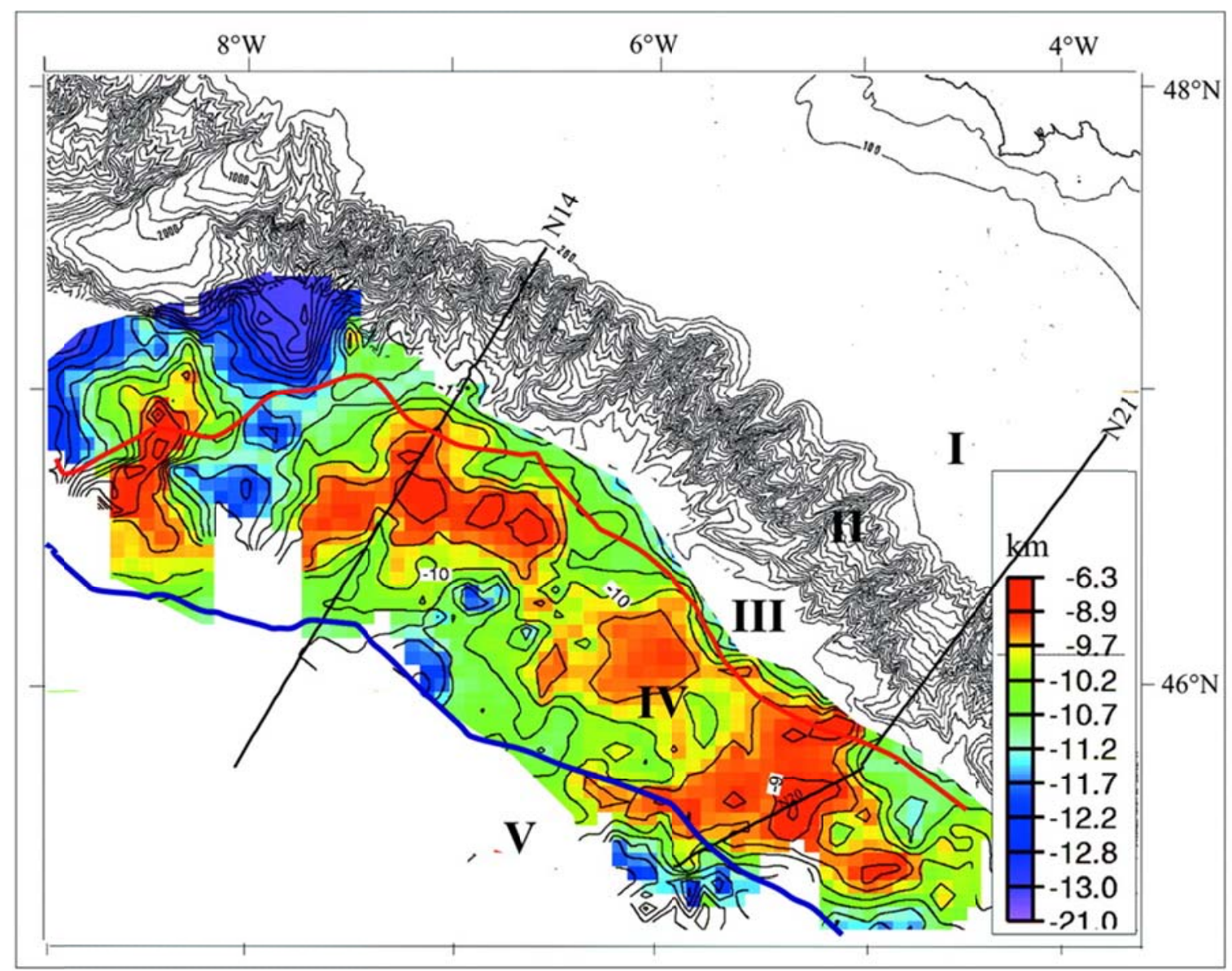

Fig. 13. Morphology and depth $(\mathrm{km})$ of the substratum of the transitional domain. The time (TWTT (s)) of the digitized MS reflector has been converted to depth $(\mathrm{km})$ with the velocities of Norgasis ocean-bottom seismometers. The magnetic (double black line) and seismic (bold blue line) oceanic limits and the limits of the continental blocks (red line) are shown.

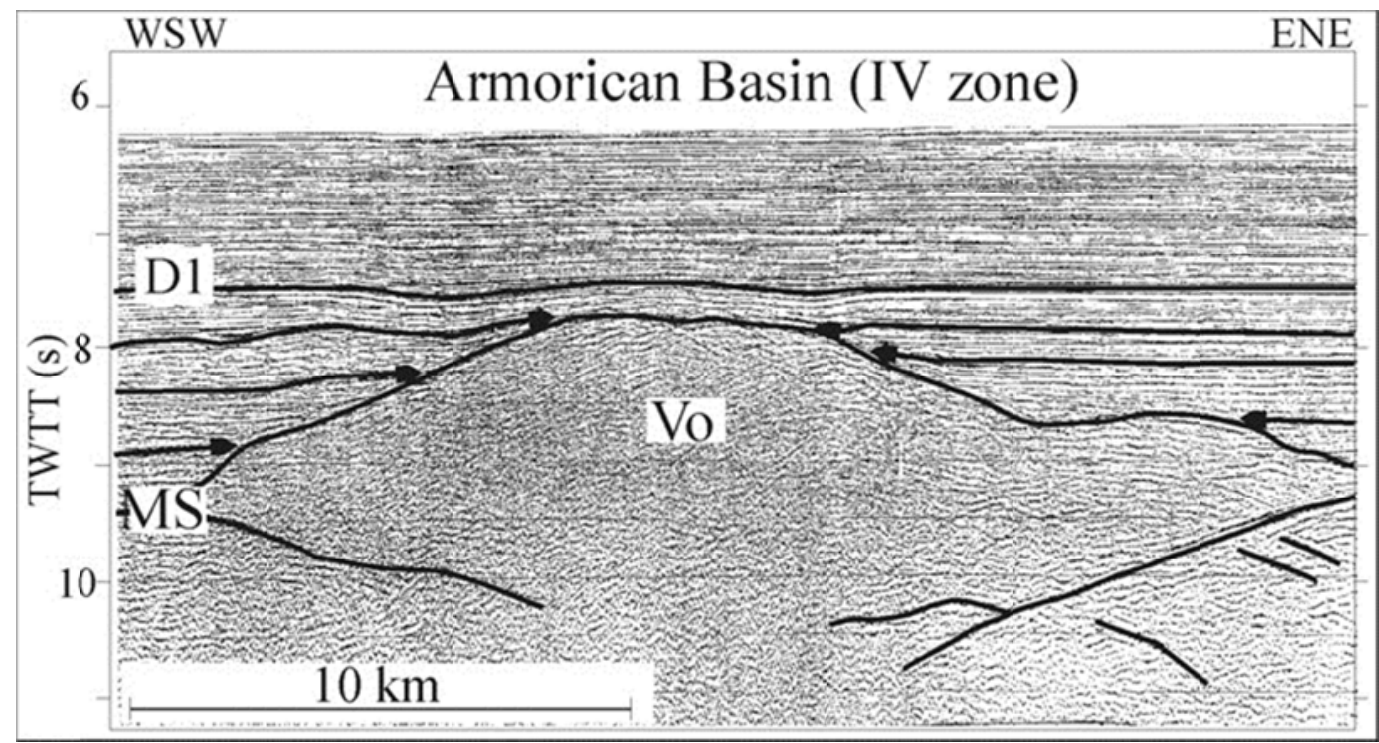

Fig. 14. An SNEAp AB640 seismic reflection profile across the body with a conical shape (for location see Fig. 6). D1, Pyrenean unconformity; MS, basement of the ocean-continent transition zone; Vo, volcanic body. 


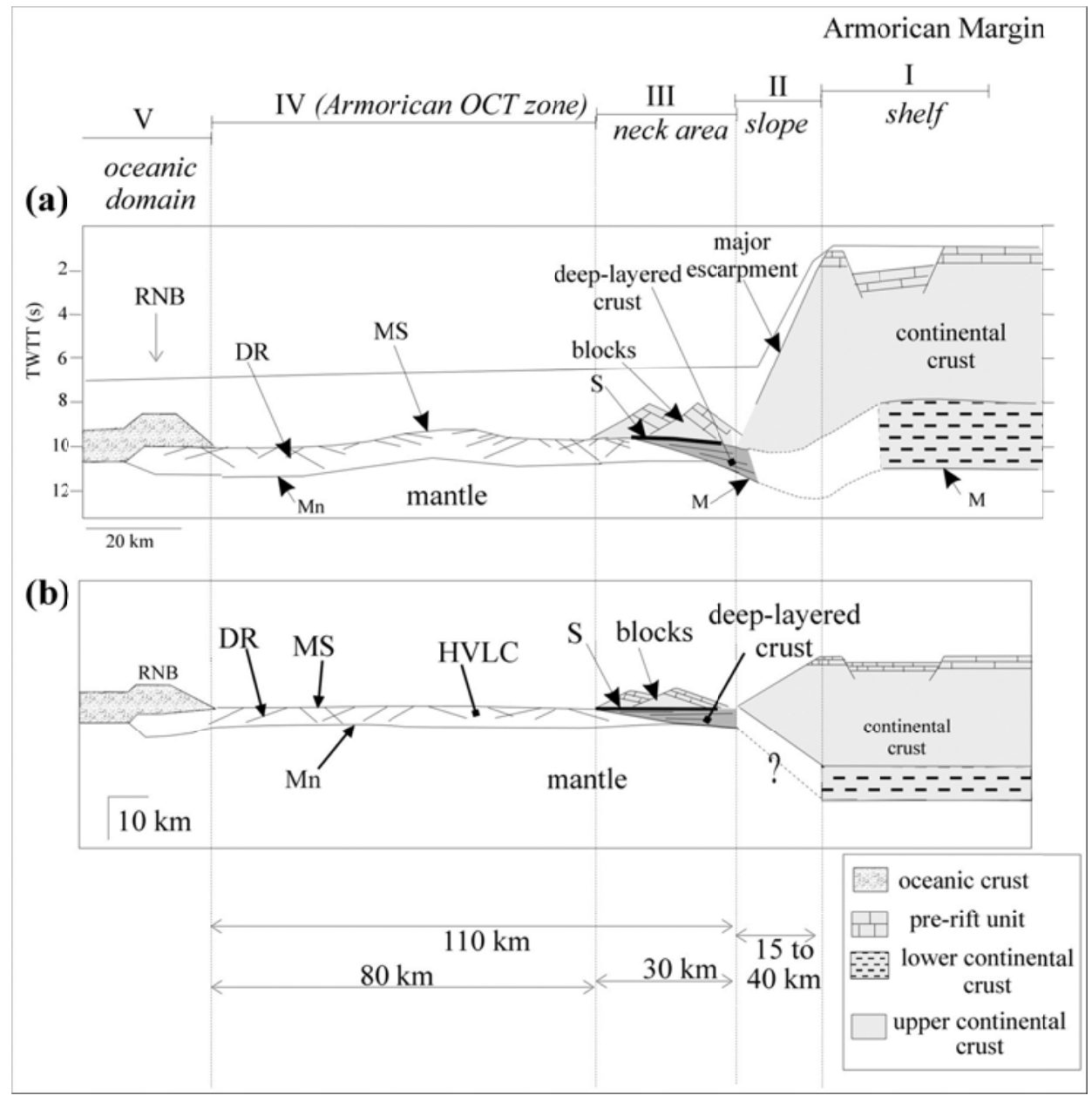

Fig. 15. Schematic illustrations of archetypal crustal section across the Armorican segment of the North Biscay margin. (a) Synthetic time section. (b) Synthetic depth section without vertical exaggeration. MS, Basement of the ocean-continent transition zone; M, Moho; DR, dipping reflectors; S, S reflector; Mn, top of the normal mantle of the Armorican Basin; HVLC, high-velocity lower-crustal layer; NBR, North Biscay Ridge.

(a) Iberia Abyssal Plain

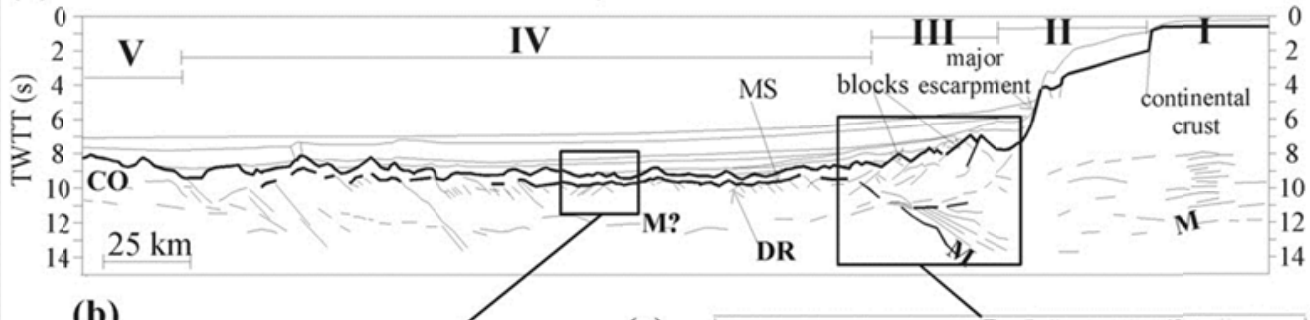

(b)

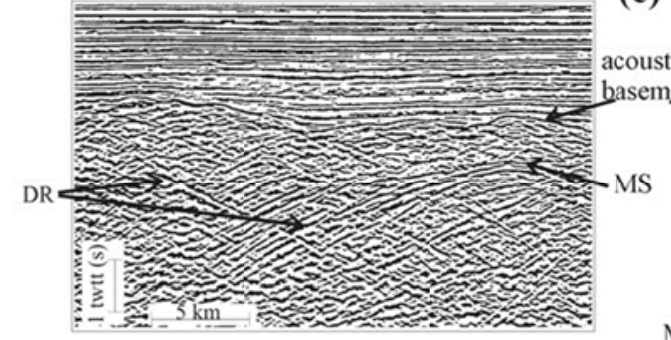

(c)

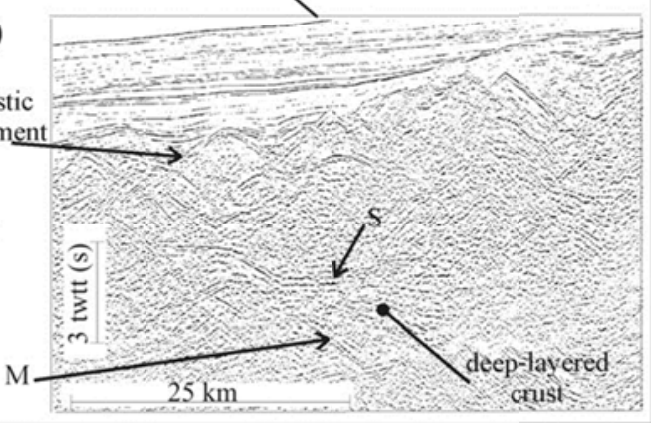

Fig. 16. (a) Reinterpreted section of IAM 9 profile across the West Iberia margin. (b) Enlargement of the acoustic basement of the ocean-continent transition zone (Pickup et al. 1996). (c) Enlargement of the deep-layered crust under the tilted blocks, at the base of the continental slope. MS, Basement of the ocean-continent transition zone; M, Moho; DR, dipping reflectors; S, S reflector; CO, oceanic crust. 